Portland State University

PDXScholar

\title{
The Effectiveness of Induced Location of Manufacturing Industry as a Means of Fostering Sustained Economic Growth in Less Developed Regions of Oregon
}

Leland F. Smith

Portland State University

Follow this and additional works at: https://pdxscholar.library.pdx.edu/open_access_etds

Part of the Economic History Commons, Industrial Organization Commons, and the Regional Economics Commons

Let us know how access to this document benefits you.

\section{Recommended Citation}

Smith, Leland F., "The Effectiveness of Induced Location of Manufacturing Industry as a Means of Fostering Sustained Economic Growth in Less Developed Regions of Oregon" (1974). Dissertations and Theses. Paper 2032.

https://doi.org/10.15760/etd.2031

This Thesis is brought to you for free and open access. It has been accepted for inclusion in Dissertations and Theses by an authorized administrator of PDXScholar. Please contact us if we can make this document more accessible: pdxscholar@pdx.edu. 
AN ABSTRACT OF THE THESIS OF Leland $F$. Smith for the Master of Arts in Economics presented March 22, 1974.

Title: The Effectiveness of Induced Location of Manufacturing Industry As A Means of Fostering Sustained Economic Growth in Less : Developed Regions of Oregon.

APPROVED BY MEMBERS OF THE THESIS COMMITTEE:

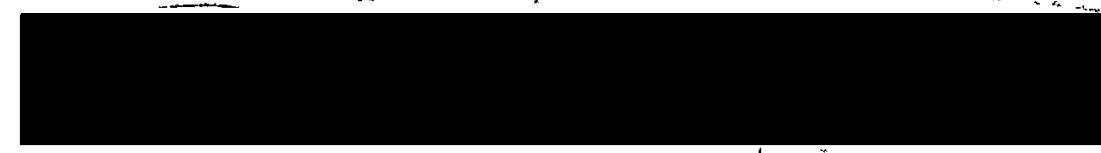

Richard B. Halley, Chairman

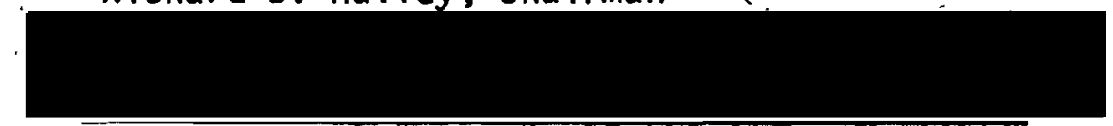

Thomas A. McLean

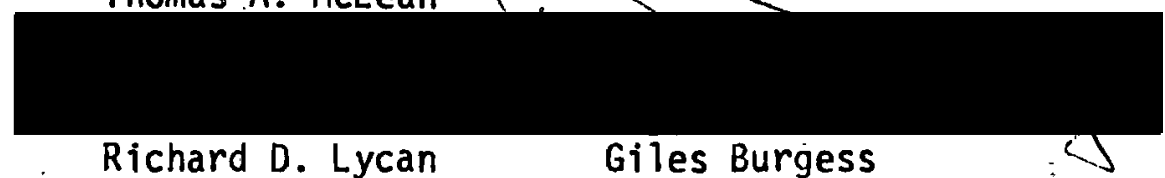

The subject of this thesis was chosen from both a professional and an academic interest in the economic development of Oregon.; Prompted by proposals made to the Oregon Legislature to initiate various forms of industrial subsidy programs to disperse economic growth and population away from congested areas, this research effort seeks to provide an evaluative analysis of the effectiveness. of subsidy techniques in influencing industrial location and stimulating a sustained growth process in less developed areas.

Research was undertaken in two primary subjects: 1) theory of regional economic development and the effects of subsidies on the growth process; and 2) empirical evidence of the effectiveness of industrial subsidy programs on regional development in other areas. Information was obtained from the following resources: 
1) The author's library of reference literature on economic development and the bibliographies contained therein;

2) Professional organizations, particularly the library of. the American Industrial Development Council, as well as requests for literature from various members of those organizations;

3) University library resources, including:

a) Bureaus of Business Research, Bibliography, 1968-1970;

b) Public Affairs Information Service, 1965-Ján. 3, 1973;

c) Business Periodicals Index; 1965-1972;

d) Journal of Economic Articles; 1967-Dec., 1972;

e) Index to Economic Literature, 1966-1970;

f) U.S. Library of Congress, National Union Catalog; 1960-1972;

g) Council of Planning Librarians, Bibliographies;

h) Colorado University, Public Catalog of Norlin Library holdings;

i) Colorado Technical Reference Center:

Using information obtained from these and other sources, a method was obtained for defining and measuring the economic and social welfare objectives of a regional development program in Oregon. Geographical patterns of economic health indicators were mapped for the state. :

This is followed by an analys is of various types of subsidies and their effects on resource allocation and gross output. It was found that wage subsidies offer optimum benefits for labor-surplus areas with less distortion of capital efficiency than do capital or price subsidies. Justification for subsidies was found to be greatest using social benefits as criteria rather than maximization of economic output.

The influence of industrial subsidies on location decisions is 
3

then examined. Following an analysis of effects of subsidies on the cost structure and profit potential for the firm, financial and tax incentives are separately reviewed in case histories of subsidy programs. "It was found that capital investment subsidies have had conoiderably more location influence than tax subsidies. In any case, however, subsidies were determined to be marginal, rather than decisive, locotonal factors with more basic economic criteria, such as labor availability, and market access; being more influential.

Finally, cost/benefit considerations for subsidy programs in Oregon are reviewed. External effects of industrialization on rural economies are considered, and the growth center concept for maximization of economic gain. is examined. Fiscal costs for state and local governgents are explored for different types of subsidy programs. The conclusion is reached that programs can be devised which minimize fiscal costs while offering maximum potential economic and social benefits. 
THE EFFECTIVENESS OF INDUCED LOCATION - OF MANUFACTURING.

\author{
INDUSTRY AS A MEANS OF FOSTERING SUSTAINED \\ ECONOMIC GROWTH IN LESS DEVELOPED \\ REGIONS OF OREGON
}

by:

LELAND F. SMITH

A thesis submitted in partial fulfiliment of the requirements for the degree of

\title{
MASTER OF ARTS
}

in

ECONOMICS

Portland State University

1974 
TO THE OFFICE OF GRADUATE STUDIES:

The members of the Committee have approved the thes is of Leland F. Smith presented March 22, 1974.

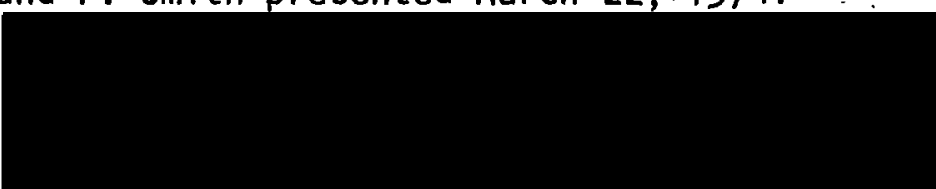

Richard B. Halley, Chairman

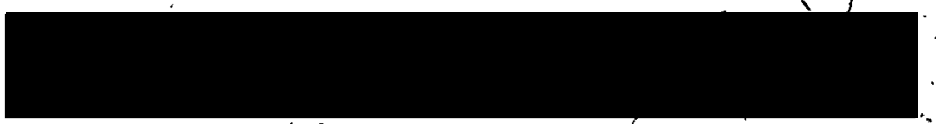

Thomas A. McLean

Richard D. Lycan/GiTes. Burgess

APPROVED:

Nelson B. Crick, Head

Denartment of Fconomics.

Gavid T. Clark; Dean

Office of Graduate Studies and Research 
PAGE

LIST OF TABLES iv

LIST OF FIGURES

\section{CHAPTER}

I - INTRODUCTION

II - OBJECTIVES AND MEASUREMENT OF REGIONAL

DEVELOPMENT IN OREGON

III TYPES OF SUBSIDIES AND THEIR EFFECTS ON RESOURCE ALLOCATION . . $. * \ldots . . . .$.

IV. - INFLUENCE OF INDUSTRIAL SUBBSIDIES ON LOCATION DECISIONS

Financiàl Incentives

Tax Incentives . . . . . . . . :

$V$ BENEFIT/COST CONSIDERATIONS FOR INDUSTRIAL

VI : CONCLUSION 


\section{LIST OF TABLES}

TABLE

PAGE

I Per Cent Population Growth in Oregon Counties, $1960^{\circ}-1970^{\circ}$

II Growth in 20-49 Age Group in Oregon Counties, $1960 \cdots 1970$

III Per Capita Income in Oregon Counties, 1969

IV Per. Cent Persons Below Poverty Income in Oregon

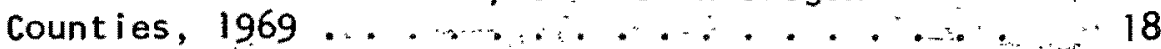

$\checkmark$ Per Cent Increase in Median Income for Families. and Unrelated Individuals, $1959-1969$

VI Per Cent Growth in Employment in Oregon Count ies, $1965-1971$

VII Per Cent Increase, Value Added by Manufacture,

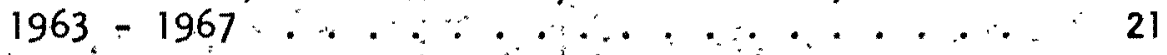

VIII $\because$ Per Cent Growth in Retail Sales in Oregon Counties; $1963-1967$. : . . : : :

IX Annual Average Total Unemployment Rates by County or Labor Market Areas, : $1962-1971$

X . Composite of Ranks

XI Interest Cost Comparison of a Tax-Exempt and Taxable Corporate Financing for a Representative: Issue of $\$ 1,000,000$ of Twenty-Year Bonds ........

XII Tax Costs as a Percentage of costs and Operation For Selected Industries and Dollar Assets. $\because \therefore \therefore$

XIII. Average Property Tax Rates in Oregon Counties; 1969-70 
LIST OF FIGURES

FIGURE

PAGE

1. Per Cent Population Change in Oregon Counties, 1960 - 1970 .

16

2 General Economic Health of Oregon as Based on Equal Weighting of Indicators

25

3. Effect of Subsidies on Location Decisions

44 
CHÁPTER I

\section{INTRODUCT ION}

A desire to alter the patterns of economic activity in the state of Oregon resulted in the creation in June, 1972, of the Oregon Senate Task Force on Economic Development. In creating the Task Force, the Oregon Senate President stated: "Population imbalance between our rural areas and the central valley core, particularly the Tri-County-Metropolitan Area, is becoming an increasing threat to both Oregon's economy and its environment." Thus: $i:$. the time has come for the Legislature to put forth a realistic package of incentives which will both. induce business away from our heavily populated areas and at the same time give our people in the rural areas an alternative to moving to the cities." "With the need and purpose thus defined, the Task Force was charged to study various programs of economic incentives and to make recommendations as to which of these programs might be applied in a coordinated state policy that would encourage industrial development in non-metropolitan parts of oregon. ${ }^{2}$

With this action, Oregon has joined with most other states in looking at means to attract industry and to influence its location within the state through the use of special incentives. The incentives

IReport of the Oregon Senate Task Force on Economic Development to the 57 th Legislative Assembly (December, 1972), p. II.

$$
{ }^{2} \text { Ib id. }
$$


that are presently employed in other areas take many different forms and are diverse in their applications and methods of administration. Analyzing the many permutations available under the various legislative programs would be beyond the scope of this study. However, a summary of state programs is provided in an appendix. They generally fall into the three classifications of (1) financial assistance for new or expanding companies, (2) tax credits for new industrial operations, and (3) special services for industrial development. ${ }^{3}$

The last of these is more of a planning and promotional tool than an inducement to industry. Such programs have become so widespread that they are more normally expected services rather than special inducements. They include the data research services of state development agencies, site location searches, various forms of technical assistance and a variety of other services by state and local agencies. State development agencies also work with local development corporations and communities within the state to help them build programs to attract industries.

As this kind of development assistance is presently available in Oregon through the Economic Development Division, this paper will be addressed to the direct subsidization proposals being considered, specifically financial and tax incentives to firms locating new facilities in designated areas of underdevelopment.

The analysis will be directed toward the economic efficiency of

3 Illustrations showing the various state programs in these three categories are included in the appendix. Data are from the 1972 site Selection Handbook, Vol. I (Atlanta: Conway Research, Inc., 1972). Various other references are included in the bibliography which also define and analyze these programs. 
the methods considered to achieve the assumed objectives of such programs, principally that the induced location of certain industrial activities will produce the stimulus for sustained growth in the beneficiary areas and that the resulting altered growth patterns will

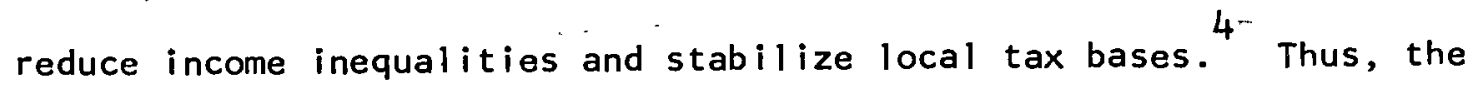
expenditure of public funds or the foregoing of tax revenues to influence the location of an industrial plant is justified in terms of the long-run economic returns that will be generated through the process of sustained growth. 5

The validity of this assumption will be assessed by an examination of the applicable principles of economic efficiency in terms of costs and benefits, and by reviewing incentive programs which have been applied in other areas and analyzing their results. While the scope of such a review must necessarily be limited, there is a growing body of literature which gives evaluative analyses of the effectiveness of incentive programs in the United States, Canada and some European nations which can be used to support some general conclusions on the subject.

This study, then, will undertake to examine the criteria by which regional economic development can be measured, to analyze the types of subsidies which might be offered, and to describe how such programs actually work to attract and disperse economic activity to designated locations. Finally, the effectiveness and social costs of industrial

4 Kenneth J. Crepas and Richard A. Stevenson, "Are Industrial Aid Bonds Fulfilling Their Intended Purpose?", Financial Analysts Journal, Vol. XXIV (November-December, 1968), p. 106.

${ }^{5}$ Industrial Aid Financing (New York: Goodbody \& Co., 1965), pp. 33-34. 
subsidization for regional development will be considered. 


\section{CHAPTER II}

\section{OBJECTIVES AND MEASUREMENT OF REGIONAL DEVELOPMENT IN OREGON}

The programs being considered in this paper have the common purpose of influencing the location of new industrial activities. Inducing a firm to build a plant in a less-developed area, however, is not sufficient for assuming that a sustained economic growth process has been stimulated. This chapter will examine the regional development process, in terms. of both economic and social benefit criteria, citing data for oregon which relates to evidence of intra-regional disparities. This, examination will provide a framework for estimating the results for Oregon of a development dispersal program, "as well as comparing those results in terms of similar national, state and local objectives.

since some basis for evaluating regional development needs to be established, a definition of the process which offers measurable criteria will be helpful to our analysis. Such a definition is offered by Krutilla, who states that:

Regional development has been defined as a process resulting in a secular rise in. regional output or real income. Increasing regional output and income implies both expansion of the region's productive capacity and growth of effective demand for the region's output... Both conditions are necessary and combined will represent a sufficient condition for regional development.

"6John V. Krutilla,."Criteria for Evaluating Regional Development Programs," in Regional Development and Planning, ed. by John Friedmann and William Alonso (Cambridge: M.I.T. Press, 1964), p. 605. 
Krutilla's definition lends itself to the economic objective of an industrial incentive program which intends to expand the productive capacity of a region by attracting new industrial facilities, thus increasing regional output and raising income levels. By including a demand function in his definition, Krutilla recognizes that expanding regional productive capacity also requires expanding demand for the region's products and that the region itself can become a larger customer for its own products by altering its industrial structure.

A problem immediately arises, however, in the determination of just what is defined as a "region." Any policy which seeks to redirect industrial activities from one area to another will have an impact beyond what can be measured in the immediate area of new investment. It has been a criticism of industrial subsidy programs that the gains they produce in one area are offset by equal or larger losses when results are measured on a broader scale. A review of programs in Canada, for example, found that the development policies carried out by provincial governments to raise growth rates in the poorer regions may also be incompatible with federal policies which are designed to increase the total national growth rate. ${ }^{7}$ The bas is for this argument is that such programs tend to misallocate resources nationally by shifting investment and production from more to less economically justifiable locations. 8

Since this paper is considering matters pertaining to government

7 Richard Hopkinson, "Government Financial Assistance for Industrial Development in Canada," The Conference Board Record, V (April, 1968), pp. 20-23.

8 Richard E. Low, "A Refinement of Local Industrial Subsidy Techniques: Comment," Mississippi Valley Journal, IV (Spring, 1969), p. 78. 
policy decisions in Oregon, a purely self-interest attitude might regard the state boundaries as delineating the region. State policies, then, would ignore external effects upon areas outside the state boundaries. Instead, the objective might be to expand the output and raise income levels for the state of Oregon regardless of the consequences of such policies on other areas.

That kind of policy, however, could not ignore the aggregate effects of altering the intra-regional industrial structure. Thus, if applying industrial subsidies only to specified areas produced a shift of resources to less efficient uses, resulting in local gains but an aggregate decline in output and incomes for the state as a whole, then efforts to improve local economies might conflict with overall goals for the state.

The problem of defining the region for measuring development gains, then, becomes very important. If limited geographical areas within the state are defined as regions, it might be possible to accomplish sectorial development objectives but only at the expense of broader state interests. An optimum might be attained, however, if development of sub-areas within the state were achieved with a corollary $r$ ise in overall output and incomes at the state and national levels.

Krutilla's definition of regional development, rooted in economic efficiency, presents us with a major concern over how the results of development policies are to be measured. The question of optimality of efficiency in resource allocation will be discussed in greater detail in the next chapter where it can be considered in terms of specific types of subsidies. For the present, it will be considered sufficient to note its importance in defining the geographical area in which 
results will be measured and judged.

Output and incomes are not the only criteria by which development programs need be measured, however. Various kinds of social benefits can also apply. In assessing the justification for reallocating capital resources, Richardson finds that the social arguments are generally stronger than economic arguments, particularly if we assume a national policy of maximizing output and further assume that firms will find their most efficient locations through free market forces. 9 Among the possible social benefits cited by Richardson are the utilization of unemployed labor, the widening of locational preferences and the reductions of diseconomies in congested areas. Richardson also cites a possible economic benefit to existing firms from creation of external economies and agglomeration effects.

Referring again to the report of the Oregon Senate Task Force on Economic Development, cited in the last chapter, there is considerable similarity between Richardson's social benefit considerations and the reasons given to justify a subsidy program in Oregon. To measure the results of a subsidy program, then, the social benefit considerations would appear to offer criteria equally valid to purely economic considerations. It would rest with the state to define the acceptable level of trade-offs between social benefits and economic costs, or between local versus statewide development objectives. To some degree, such decisions will be affected by the relative efficiencies of various types of subsidy programs, and these will be examined in the next chapter.

However, the social benefit argument depends upon the assumption

9 Harry W. Richardson, Regional Economics (New York: Praeger, 1969), pp. 386-428. 
that there are, in fact, certain disparities which could be corrected by use of a subsidy program to disperse economic activities within the state. In order to assess the need for, and potential benefits of, any State programs to encourage the dispersal of population and economic growth in Oregon, some prel iminary recognition should be given to the existing geographic patterns of major economic indicators within the state. Fortunately, a model for doing this was developed in 1960 for New York state by a team of researchers from Syracuse University. 10 Among the conclusions stated in their report is. that: "The procedures employed in this analysis of New York state could be applied to any part. of the United States, and theoretically at least, to any part of the world."l! On this basis, their model is herein applied, with modifications, to Oregon".

Beginning with the recognition that no single indicator is suffi-. cient to measure either the level or trend of economic health, the model, uses a composite of nine indicators which the authors felt were significant: Counties were used as the statistical unit because of the wide variety of economic data available. The nine indicators used in the ir analysis were sas follows:

Per Capita Income, 1958. By implication, the higher the per capita income, the better the economic health: This indicator "measures the relative levels of economic health between counties.

Increase in Per Cap ita Income, 1950-1957. The implication is that

10 John H. Thompson, Sydney C. Sufrin, Peter R. Gould, and Marion A. Buck, "Toward A Geography of Economic Health: The Case of New York" State," in Regional Development and Planning, op. cit., pp. 187-206.

11 Ibid.; p. 206. 
the greater the increase in per capita income, the better the economic health. This is a trend indicator so the geographical pattern would not necessarily conform to that shown by income levels.

Average Unemployment, 1949-1958. Lower unemployment levels would imply better economic health. This is also useful as a separate item for analysis as unemployment is the indicator most widely used to identify economic distress.

Per Cent Growth of Total Employment, 1947-1956. This trend indicator implies that the higher the growth rate, the better the economic health.

Per Cent Growth of Population, 1950-1956. Higher population growth rates generally imply a trend toward better economic health. Except for the suburbanization phenomena, it is not likely that large population gains would occur in any area that does not provide economic support. Declines in population would be expected to reflect limited or declining employment opportunities.

Per Cent Population in 20-49 Year Age Group, 1950. This is

essentially the working force age group, so larger percenteges would reflect higher levels of economic health.

Per Cent Increase in Value Added by Manufacture, 1947-1954. It is implied by this trend indicator that the greater the increase, the better the economic health.

Per Cent Growth in Retail Sales, 1948-1958. Retail sales growth is implied to show a trend in economic health.

Increase in Annual Average Weekly Wage and Salary Earnings, 1950-

1958. This trend indicator implies a direct relationship between the size of the increase and the economic health of the statistical unit. 
It will be noted that these nine indicators measure both levels and trends of economic health. Their composite, then, gives a geographic pattern which reflects both static and dynamic elements in the state's economy.

This study proceeded to give the rank order of counties by each. indicator, then to sum the ranks and give a new rank order based on an equal-weighting composite. The result was divided into quintiles which were graphically recorded on a state map showing county boundaries. "This map, labeled "General Economic Health (as based on equal weighting),". provided a visual pattern of economic health in the state of New York.

In, applying this model. to Oregon; certain problems emerged with the data. Statistics on unemployment, for example, are generally available.for counties except where the Oregon State Employment Division uses the. "Labor Market Area" concept. Under that concept, the Division uses a single statistic for combinations of Marion and Polk counties; Sherman and Wasco counties; Multnomah, Clackamas and Washington counties combined with Clark County, Washington; and Malheur County combined with Payette and Washington counties in Idaho: In those instances, the single labor market area, rate of unemployment was used for each" oregon county within that area. It would be expected that using this multicounty average would produce different results than if each county had been measured separatêly. However, since county boundaries are arbitrary and the purpose of this report is to identify general economic patterns; the result of ising the labor market area concept in these few instances should not appreciably alter the validity of this indicator of economic health. 
A greater problem occurred with the value added data. Because of the small number of manufacturing establishments in several counties, data were withheld from publication for seven counties to avoid disclosure for individual firms. In those cases, the rank order compos-ites were based on eight indicators, rather than nine, and welighted accordingly. It should be further realized, however, that where the manufacturing base is small or concentrated into single industries, as is the case in much of Oregon, then this, indicator is subject to wide fluxuations from relatively small absolute changes. 'Since the ultimate purpose of this analysis is to prepare the groundwork for programs aimed at dispersing manufacturing employment, however, this indicator was retained as significant for that purpose.

Finally, the increase in annual average weekly wage and salary earnings proved simply to not be available." However, the 1970 Census of Population provided a useful measure of economic health which was not available when the New York model was developed. "This measure was the percentage of persons earning below the poverty level of income in 1969. This seemed suitably significant to substitute it for the missing indicator based on earnings.

Using more current data, then, the following indicator.s. were utilized in determining the geographic pattern of economic health in Oregon:

1. Per Cent Population Growth; 1960-1970.

2. Per Cent Growth in 20-49 Age Group, 1960-1970.

3. Per Capita Income, 1969.

4. Per Cent of Persons Below Poverty Level of Income, 1969.

5. Per Cent Increase in Median Income for Families and Unrelated Individuals, 1959-1969. 
6. Per Cent Growth in Employment, 1965-1971.

7. Per Cent Increase in Value Added by Manufacture, 1963-1967.

8. Per Cent Growth in Retail Sales, 1963-1967.

9. Average Total Unemployment Rate, 1962-1971.

On the basis of the county rankings for each indicator, the composite was drawn and mapped by quartiles. The result is the map showing the General Economic Health for Oregon as Based on Equal. Weighting of Indicators (Figure 1 ).

The patterns produced by this model were predictable in several instances but also presented a few surprises. of the nine counties in the first quartile, six are in the upper Willamette Valley, as expected.: The other three, however, are located in central and eastern Oregon. Deschutes, Harney and Union counties generally ranked in the upper half of all indicators and showed sufficient strength in one or more categories to achieve that first quartile ranking.

In the second quartile, four of the nine counties lie in the Willamette Valley, placing all of the counties in this valley in the upper half. The other counties in the second quartile include Jackson and Klamath, in southern oregon; Clatsop; in northwest Oregon; and Crook and Umatilla in the eastern part of the state.

Counties in the third quartile show uneven geographic distribution, as do those in the fourth.: While counties in central and eastern oregon are often regarded as most in need of economic stimulation, coastal counties also generally show lower levels of economic health. It is. also worth noting that the presence of a regional urban center within a county does not necessarily lead to higher levels of economic health than exists in counties which are entirely rural in character. "Thus, 
Douglas County, which contains the urban center of Roseburg, ranked in the third quartile and Josephine County, where Grants Pass is located, ranked in the fourth.

The data included in the tables provide the basis for much more thorough discussion on the relative problems of Oregon counties and are included for that purpose. It would be worth exploring, for example, whether Harney County's low unemployment rate was due to sufficient opportunities to meet the demand or, instead, to a known lack of opportunities which cause unemployed persons to move away or drop. out of the labor force. In Jackson and Josephine counties, relatively high levels of population growth coupled with poorer performance in the income indicators might warrant examination into the types of people moving into southern Oregon; e.g., if a disproportionate share of the increase is caused by in-migration of low-income retirees, then how does this affect the need for additional employment opportunities?

other indicators could also be added and measured to provide knowledge on subjects of specific interest; e.g., assessed valuations, tax revenues, and general expenditures of counties to measure the economic health of local governments. The usefulness of such indicators may depend upon certain assumptions and value judgements, however, so they should be analyzed carefully. For the purposes of this paper, the establishment of the rank order and mapping based upon the modified New York model has been deemed sufficient.

With this geographic portrayal of the general economic health of Oregon, efforts can now follow to explore means of altering the estab1 ished economic patterns through State-directed programs aimed at dispersion of economic opportunities and population growth. 
TABLE I

PER CENT POPULATION GROWTH IN OREGON COUNTIES, $1960-1970$

\begin{tabular}{|c|c|c|c|c|c|}
\hline RANK & COUNTY & 1970 & 1960 & CHANGE & PER CENT CHANGE \\
\hline $\begin{array}{r}34 \\
3 \\
2 \\
21 \\
7 \\
22 \\
17 \\
28 \\
5 \\
19 \\
35 \\
30 \\
14 \\
26 \\
8 \\
12 \\
13 \\
18 \\
31 \\
6 \\
20 \\
11 \\
23 \\
9 \\
29 \\
16 \\
4 \\
33 \\
27 \\
24 \\
15 \\
32 \\
25 \\
1 \\
36 \\
10\end{array}$ & $\begin{array}{l}\text { BAKER } \\
\text { BENTON } \\
\text { CLACKAMAS } \\
\text { CLATSOP } \\
\text { COLUMB IA } \\
\text { COOS } \\
\text { CROOK } \\
\text { CURRY } \\
\text { DESCHUTES } \\
\text { DOUGLAS } \\
\text { GILLIAM } \\
\text { GRANT } \\
\text { HARNEY } \\
\text { HOOD RIVER } \\
\text { JACKSON } \\
\text { JEFFERSON } \\
\text { JOSEPHINE } \\
\text { KLAMATH } \\
\text { LAKE } \\
\text { LANE } \\
\text { LINCOLN } \\
\text { LINN } \\
\text { MALHEUR } \\
\text { MARION } \\
\text { MORROW } \\
\text { MULTNOMAH } \\
\text { POLK } \\
\text { SHERMAN } \\
\text { TILLAMOOK } \\
\text { UMATILLA } \\
\text { UNION } \\
\text { WALLOWA } \\
\text { WASCO } \\
\text { WASHINGTON } \\
\text { WHEELER } \\
\text { YAMHILL }\end{array}$ & $\begin{array}{r}14,919 \\
53,776 \\
166,088 \\
28,473 \\
28,790 \\
56,515 \\
9,985 \\
13,006 \\
30,442 \\
71,743 \\
2,342 \\
6,996 \\
7,215 \\
13,187 \\
94,533 \\
8,548 \\
35,746 \\
50,021 \\
6,343 \\
213,358 \\
25,755 \\
71,914 \\
23,169 \\
151,309 \\
4,465 \\
556,667 \\
35,349 \\
2,139 \\
17,930 \\
44,923 \\
19,377 \\
6,247 \\
20,133 \\
157,920 \\
1,849 \\
40,213\end{array}$ & $\begin{array}{r}17,295 \\
39,165 \\
113,038 \\
27,380 \\
22,379 \\
54,955 \\
9,430 \\
13,983 \\
23,100 \\
68,458 \\
3,069 \\
7,726 \\
6,744 \\
13,395 \\
73,962 \\
7,130 \\
29,917 \\
47,475 \\
7,158 \\
162,890 \\
24,635 \\
58,867 \\
22,764 \\
120,888 \\
4,871 \\
522,813 \\
26,523 \\
2,446 \\
18,955 \\
44,352 \\
18,180 \\
7,102 \\
20,205 \\
92,237 \\
2,722 \\
32,478\end{array}$ & $\begin{array}{r}-2,376 \\
14,611 \\
53,050 \\
1,093 \\
6,411 \\
1,560 \\
555 \\
-977 \\
7,342 \\
3,285 \\
-727 \\
-730 \\
471 \\
-208 \\
20,571 \\
1,418 \\
5,829 \\
2,546 \\
-815 \\
50,468 \\
1,120 \\
13,047 \\
405 \\
30,421 \\
-406 \\
33,854 \\
8,826 \\
-307 \\
-1,025 \\
571 \\
1,197 \\
-855 \\
-722 \\
65,683 \\
-873 \\
7,735\end{array}$ & $\begin{array}{r}-13.7 \\
37.4 \\
46.9 \\
4.0 \\
28.6 \\
2.8 \\
5.9 \\
-7.0 \\
31.8 \\
4.8 \\
-23.6 \\
-9.5 \\
7.0 \\
-1.7 \\
27.8 \\
19.9 \\
19.5 \\
5.4 \\
-11.8 \\
31.0 \\
4.5 \\
22.2 \\
1.8 \\
25.2 \\
-8.3 \\
6.5 \\
33.2 \\
-12.5 \\
-5.4 \\
1.3 \\
6.6 \\
-12.1 \\
-0.4 \\
71.2 \\
-32.1 \\
23.8\end{array}$ \\
\hline State & of Oregon & $2,091,385$ & $1,768,687$ & 322,698 & 18.2 \\
\hline
\end{tabular}

Source: U.S. Department of Commerce, Bureau of the Census, Census of Population: 1970 (Washington: U.S. Government Printing Office), PC(1)-C39. Changes calculated by the author. 
FIGURE i

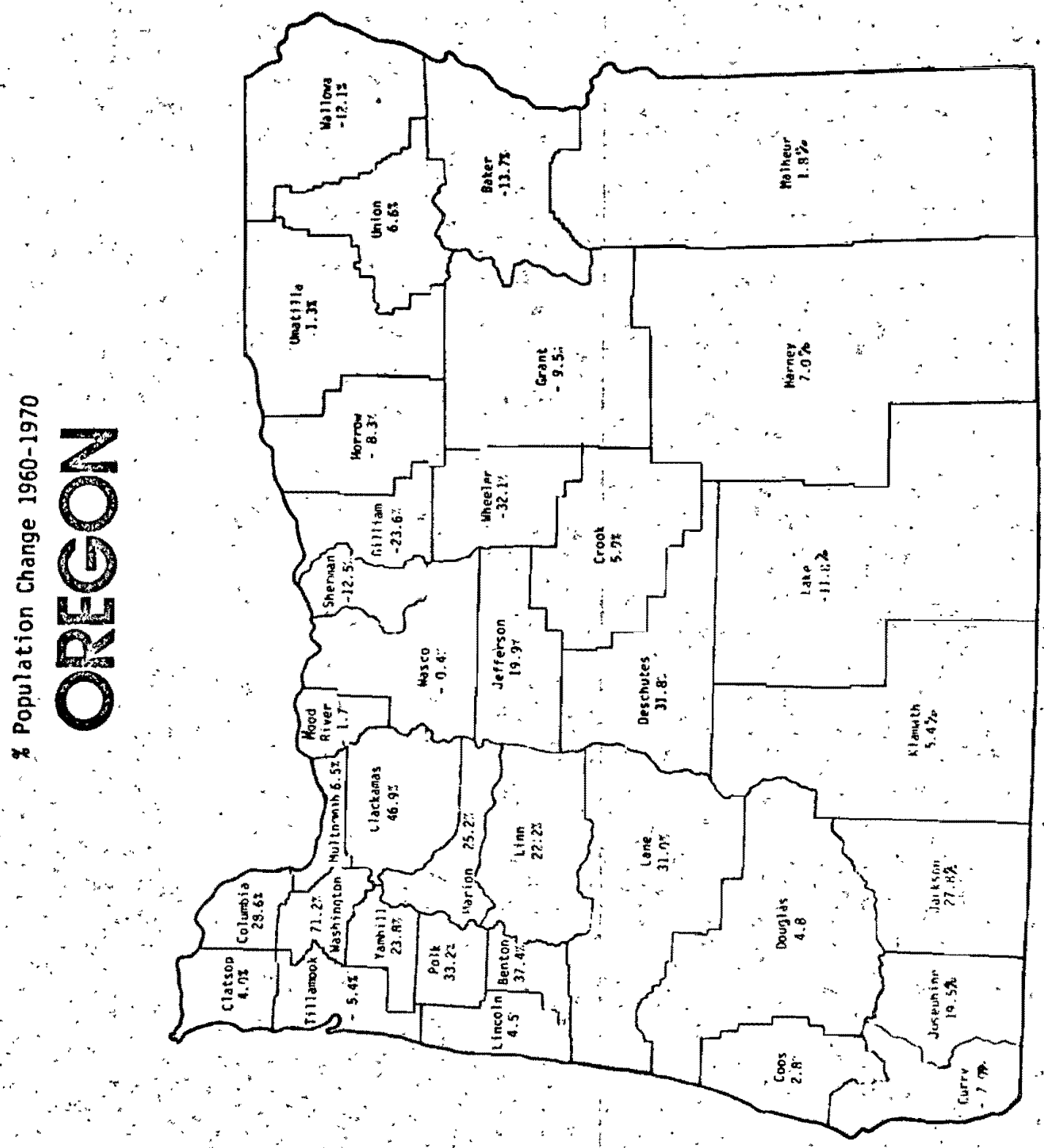


TABLE II

GROWTH IN 20-49 AGE GROUP IN OREGON COUNTIES $1960-1970$

\begin{tabular}{|c|c|c|c|c|c|}
\hline RANK & COUNTY & 1970 & 1960 & CHANGE & $\%$ CHANGE \\
\hline 34 & BAKER & 4,695 & 6,045 & $-1,350$ & -22 \\
\hline 3 & BENTON & 23,906 & 16,429 & 7,477 & 45.5 \\
\hline 2 & CLACKAMAS & 62,014 & 40,938 & 21,076 & 51.5 \\
\hline $2 \overline{4}$ & CLATSOP & 9,202 & 9,625 & -423 & -4.4 \\
\hline 7 & COLUMB IA & 10,034 & 7,586 & 2,448 & 32. \\
\hline 22 & coos & 20,299 & 21,197 & -898 & -4 \\
\hline 18 & CROOK & 3,504 & 3,521 & -17 & -0.5 \\
\hline 33 & CURRY & 4,332 & 5,448 & $-1,116$ & -20.5 \\
\hline 8 & DESCHUTES & 10,650 & 8,277 & 2,373 & 28.7 \\
\hline 19 & DOUGLAS & 25,548 & 25,778 & -230 & -0.9 \\
\hline 35 & GILLIAM & 819 & 1,216 & -397 & -32.6 \\
\hline 30 & GRANT & 2,384 & 2,849 & -465 & -16 \\
\hline 16 & HARNEY & 2,699 & 2,631 & 68 & 2.6 \\
\hline 28 & HOOD RIVER & 4,347 & 4,708 & -361 & -7.7 \\
\hline 9 & JACKSON & 33,664 & 26,647 & 7,017 & 26. \\
\hline 12 & JEFFERSON & 3,049 & 2,740 & 309 & 11.6 \\
\hline 13 & JOSEPHINE & 11,224 & 10,158 & 1,066 & 10.5 \\
\hline 17 & KLAMATH & 19,007 & 18,767 & 240 & 1.3 \\
\hline 32 & LAKE & 2,181 & 2,741 & -560 & -20.4 \\
\hline 6 & LANE & 83,869 & 63,151 & 20,718 & 32.8 \\
\hline 25 & LINCOLN & 7,918 & 8,396 & -478 & -5.7 \\
\hline 11 & LINN & 25,785 & 21,321 & 4,464 & 20. \\
\hline 23 & MALHEUR & 7,504 & 7,839 & -335 & -4.3 \\
\hline 4 & MAR ION & 61,495 & 42,613 & 18,882 & 44.4 \\
\hline 20 & MORROW & 1,431 & 1,727 & -296 & -1.7 \\
\hline 15 & MULTNOMAH & 205,727 & 192,317 & 13,410 & 7. \\
\hline 5 & POLK & 12,695 & 9,353 & 3,342 & 35 . \\
\hline 27 & SHERMAN & 864 & 930 & -66 & -7 \\
\hline 29 & TILLAMOOK & 5,696 & 6,617 & -921 & -13. \\
\hline 21 & UMATILLA & 15,522 & 15,993 & -471 & -2 \\
\hline 14 & UNION & 6,786 & 6,337 & 449 & 7 . \\
\hline 31 & WALLOWA & 2,051 & 2,549 & -498 & -19. \\
\hline 26 & WASCO & 6,915 & 7,434 & -519 & -7 \\
\hline 1 & WASHINGTON & 62,723 & 34,051 & 28,672 & 84. \\
\hline 36 & WHEELER & 619 & 1,027 & -408 & -39.7 \\
\hline 10 & YAMH ILL & 13,443 & 10,741 & 2,702 & 25.1 \\
\hline
\end{tabular}

Source: U.S. Department of Commerce, Bureau of the Census, Census of Population: 1970 (Washington: U.S. Government Printing Office), PC(1)-C39. Changes calculated by the author. 
TABLE III

PER CAPITA INCOME IN OREGON COUNTIES, 1969

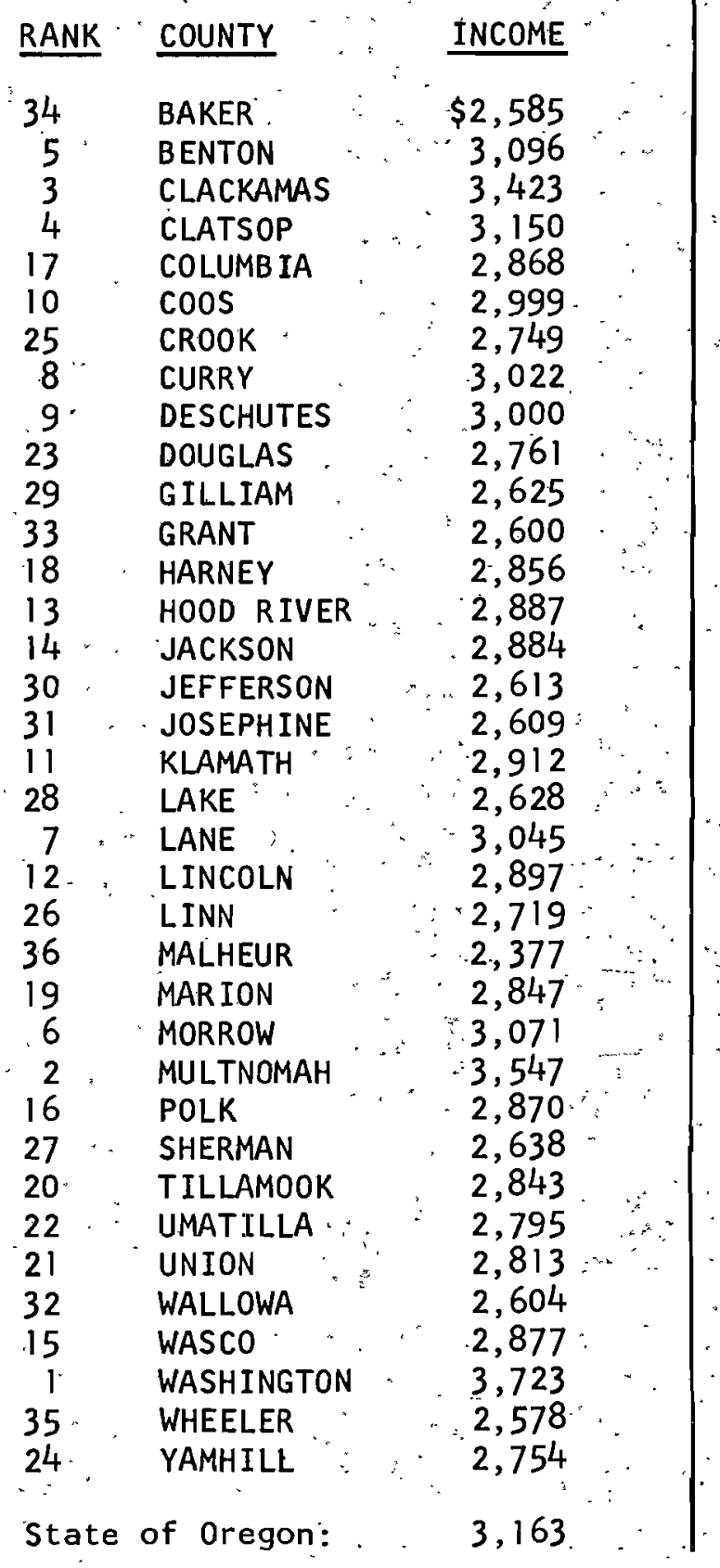

TABLE IV

PER CENT PERSONS BELOW POVERTY INCOME IN OREGON COUNTIES, 1969

\section{RANK : PERCENTAGE}

34

$28 \%$

16.7

14.8

2

25

$7 \%$

$7 *$

$22 \%$

15

$22 \%$

3

18

4

27

17

$28 \%$

35

16

31

$9 \%$

$28 *$

13

36

$19 *$

14

12

26

32

24

21

6

33

$9 \%$

1

$9 \%$

$19 *$
8.3

13.6

11.0

10.3

11.0

13.3

11.9

13.3

8.9

12.8

9.2

$13.8^{\circ}$

12.6

14.8

16.8

12.4

15.0

11.1

14.8

11.4

20.1

13.0

11.5

11.3

13.7

15.2

13.4

13.1

10.8

$15: 7$

$11: 1$

6.3

11.1

13.0

11.5

Note*: Where percentages were equal, the same rankings were given.

Source: U.S. Department of Commerce, Bureau of the Census, Census of Population: 1970 (Washington: U.S. Government Printing Office), PC(1)-C39. 
TABLE V

PER CENT INCREASE IN MEDIAN INCOME FOR FAMILIES

AND UNRELATED INDIVIDUALS, 1959 - 1969

\begin{tabular}{|c|c|c|c|c|c|}
\hline RANK & COUNTY & 1969 & 1959 & CHANGE & $\%$ CHANGE \\
\hline 30 & BAKER & $\$ 6,228$ & $\$ 4,517$ & $\$ 1,711$ & 37.9 \\
\hline 36 & BENTON & 3,722 & 3,635 & & 2.4 \\
\hline 3 & CLACKAMAS & 9,409 & 5,532 & 3,877 & 70.0 \\
\hline 15 & CLATSOP & 6,633 & 4,523 & 2,110 & 46. \\
\hline 1 & COLUMB IA & 8,260 & 4,709 & 3,551 & 75.4 \\
\hline 12 & $\operatorname{coos}$ & 8,010 & 5,334 & 2,676 & 50.2 \\
\hline 25 & CROOK & 7,289 & 5,197 & 2,092 & 40.3 \\
\hline 31 & CURRY & 7,563 & 5,506 & 2,057 & 37.3 \\
\hline 11 & DESCHUTES & 7,666 & 5,068 & 2,598 & 51.3 \\
\hline 17 & DOUGLAS & 7,730 & 5,299 & 2,431 & 45.9 \\
\hline 4 & GILLIAM & 7,451 & 4,425 & 3,026 & 68.4 \\
\hline 24 & GRANT & 7,007 & 4,976 & 2,031 & 40.8 \\
\hline 6 & HARNEY & 7,429 & 4,554 & 2,875 & 63.2 \\
\hline 21 & HOOD R IVER & 7,195 & 4,976 & 2,219 & 44.6 \\
\hline 28 & JACKSON & 6,918 & 4,982 & 1,936 & 38.9 \\
\hline 19 & JEFFERSON & 7,507 & 5,175 & 2,332 & 45.0 \\
\hline 32 & JOSEPHINE & 6,118 & 4,543 & 1,575 & 34.7 \\
\hline 26 & KLAMATH & 7,202 & 5,140 & 2,062 & 40.2 \\
\hline 33 & LAKE & 6,993 & 5,391 & 1,602 & 29.7 \\
\hline 27 & LANE & 7,309 & 5,227 & 2,082 & 39.8 \\
\hline 29 & LINCOLN & 6,244 & 4,513 & 1,731 & 38.4 \\
\hline 8 & LINN & 7,902 & 5,051 & 2,851 & 56.4 \\
\hline 18 & MALHEUR & 5,960 & 4,083 & 1,877 & 45.9 \\
\hline 9 & MAR ION & 7,250 & 4,646 & 2,604 & 56. \\
\hline 13 & MORROW & 7,160 & 4,823 & 2,337 & 48. \\
\hline 20 & MULTNOMAH & 7,527 & 5,205 & 2,322 & 44.7 \\
\hline 22 & POLK & 6,539 & 4,544 & 1,995 & 44.0 \\
\hline 35 & SHERMAN & 6,947 & 5,636 & 1,311 & 23.3 \\
\hline 16 & TILLAMOOK & 6,946 & 4,756 & 2,190 & 46.1 \\
\hline 23 & UMATILLA & 7,251 & 5,092 & 2,159 & 42.4 \\
\hline 7 & UNION & 6,720 & 4,200 & 2,520 & 60.0 \\
\hline 14 & WALLOWA & 6,915 & 4,402 & 2,513 & 47.1 \\
\hline 10 & WASCO & 8,001 & 5,223 & 2,778 & 53.2 \\
\hline 2 & WASHINGTON & 10,083 & 5,863 & 4,220 & 72.2 \\
\hline 34 & WHEELER & 6,373 & 5,161 & 1,212 & 23.5 \\
\hline 4 & YAMHILL & 6,577 & 3,935 & 2,642 & \\
\hline
\end{tabular}

Source: U.S. Department of Commerce, Bureau of the Census, Census of Population: 1970 (Washington: U.S. Government Printing Office), $\overline{P C}(1)-39$. Changes calculated by the author. 
TABLE VI

PER CENT GROWTH IN EMPLOYMENT IN OREGON COUNTIES, 1965 - 1971

\begin{tabular}{|c|c|c|c|c|c|}
\hline RANK & COUNTY & 1971 & 1965 & CHANGE & $\%$ CHANGE \\
\hline 17 & BAKER & 2,691 & 2,320 & 371 & 16.0 \\
\hline 7 & BENTON & 8,948 & 6,891 & 2,057 & 29.8 \\
\hline 2 & CLACKAMAS & 24,083 & 16,752 & 7,331 & 43.7 \\
\hline 23 & CLATSOP & 6,429 & 5,940 & 489 & 8.2 \\
\hline 19 & COLUMB IA & 3,823 & 3,382 & 441 & 13.1 \\
\hline 24 & $\operatorname{coos}$ & 13,958 & 12,883 & 1,075 & 8.1 \\
\hline 4 & CROOK & 2,630 & 1,878 & 752 & 40.0 \\
\hline 30 & CURRY & 2,829 & 2,904 & -75 & -2.5 \\
\hline 6 & DESCHUTES & 7,054 & 5,160 & 1,894 & 36.8 \\
\hline 29 & DOUGLAS & 16,195 & 16,587 & -392 & -2.4 \\
\hline 35 & GILLIAM & 304 & 789 & -485 & -61.4 \\
\hline 8 & GRANT & 1,082 & 841 & 241 & 28.7 \\
\hline 27 & HARNEY & 1,492 & 1,494 & -2 & -0.1 \\
\hline 21 & HOOD RIVER & 2,658 & 2,368 & 290 & 12.2 \\
\hline 11 & JACKSON & 20,422 & 16,677 & 3,745 & 22.5 \\
\hline 34 & JEFFERSON & 1,376 & 1,667 & -291 & -17.4 \\
\hline 25 & JOSEPH INE & 6,197 & 5,926 & 271 & 4.6 \\
\hline 16 & KLAMATH & 10,523 & 8,888 & 1,635 & 18.4 \\
\hline 33 & LAKE & 920 & 1,070 & -150 & -14.0 \\
\hline 22 & LANE & 50,214 & 46,099 & 4,115 & 8.9 \\
\hline 28 & LINCOLN & 4,867 & 4,979 & -112 & -2.3 \\
\hline 12 & LINN & 17,530 & 14,348 & 3,182 & 22.2 \\
\hline 14 & MALHEUR & 5,420 & 4,475 & 945 & 21.1 \\
\hline 13 & MARION & 29,060 & 23,892 & 5,168 & 21.6 \\
\hline 9 & MORROW & 438 & 345 & 93 & 26.9 \\
\hline 15 & MULTNOMAH & 227,100 & 188,776 & 38,324 & 20.3 \\
\hline 18 & POLK & 4,784 & 4,144 & 640 & 15.4 \\
\hline 36 & SHERMAN & 172 & $506 \%$ & -334 & -66.0 \\
\hline 20 & TILLAMOOK & 3,312 & 2,945 & 367 & 12.5 \\
\hline 10 & UMATILLA & 8,478 & 6,845 & 1,633 & 23.9 \\
\hline 3 & UNION & 3,817 & 2,705 & 1,112 & 41.1 \\
\hline 31 & WALLOWA & 646 & 698 & -52 & -7.4 \\
\hline 26 & WASCO & 3,848 & 3,794 & 54 & 1.4 \\
\hline 1 & WASHINGTON & 28,076 & 18,451 & 9,625 & 52.2 \\
\hline 32 & WHEELER & 283 & 325 & -42 & -12.9 \\
\hline 5 & YAMHILL & 7,441 & 5,320 & 2,121 & 40.0 \\
\hline
\end{tabular}

Note*: 1964 employment is shown, as 1965 employment was substantially inflated by construction projects.

Source: U.S. Department of Commerce, Bureau of the Census, County Bus iness Patterns: 1965 and 1971 (Washington: U.S. Government Printing office). 
TABLE VII

PER CENT INCREASE, VALUE ADDED BY MANUFACTURE, 1963 - 1967 (Thousands of Dollars)

\begin{tabular}{|c|c|c|c|c|c|}
\hline RANK & COUNTY & 1967 & 1963 & CHANGE & $\%$ CHANGE \\
\hline 8 & BAKER & 9,000 & 6,400 & 2,600 & 40.6 \\
\hline 16 & BENTON & 28,400 & 22,100 & 6,200 & 28.0 \\
\hline 13 & CLACKAMAS & 109,900 & 81,200 & 28,700 & 35.4 \\
\hline 10 & CLATSOP & 36,100 & 26,100 & 10,000 & 38.3 \\
\hline 22 & COLUMB IA & 32,500 & 31,900 & 600 & 1.9 \\
\hline 20 & coos & 79,800 & 69,200 & 10,600 & 15.3 \\
\hline 3 & CROOK & 15,300 & 8,800 & 6,500 & 74.0 \\
\hline 23 & CURRY & 22,200 & 22,300 & -100 & -0.5 \\
\hline 5 & DESCHUTES & 20,100 & 13,500 & 6,600 & 48.8 \\
\hline 17 & DOUGLAS & 103,500 & 83,300 & 20,200 & 24.2 \\
\hline - & GILLIAM & $D$ & 100 & - & - \\
\hline 28 & GRANT & 2,700 & 5,200 & $-2,500$ & -48.2 \\
\hline - & HARNEY & $D$ & D & - & \\
\hline 18 & HOOD RIVER & 13,000 & 10,900 & 2,100 & 19.3 \\
\hline 15 & JACKSON & 77,600 & 59,800 & 17,800 & 29.8 \\
\hline - & JEFFERSON & D & 7,600 & - & - \\
\hline 19 & JOSEPHINE & 30,000 & 25,600 & 4,400 & 17.2 \\
\hline 11 & KLAMATH & 36,100 & 26,200 & 9,900 & 37.4 \\
\hline 24 & LAKE & 5,500 & 6,300 & -800 & -12.7 \\
\hline 21 & LANE & 208,200 & 183,600 & 24,600 & 13.4 \\
\hline 27 & LINCOLN & 17,700 & 24,200 & $-6,500$ & -26.9 \\
\hline 4 & LINN & 111,900 & 72,500 & 39,400 & 54.4 \\
\hline - & MALHEUR & 22,700 & D & - & - \\
\hline 14 & MARION & 89,700 & 68,500 & 21,200 & 30.9 \\
\hline - & MORROW & 2,200 & D & - & $0^{-1}$ \\
\hline 9 & MULTNOMAH & 650,800 & 470,100 & 180,700 & 38.4 \\
\hline 25 & POLK & 31,600 & 36,600 & $-5,000$ & -13.7 \\
\hline- & SHERMAN & $z$ & D & - & \\
\hline 6 & TILLAM0OK & 19,800 & 13,500 & 6,300 & 46.7 \\
\hline 7 & UMATILLA & 35,800 & 24,800 & 11,000 & 44.4 \\
\hline 1 & UNION & 14,600 & 6,600 & 8,000 & 121.2 \\
\hline 29 & WALLOWA & 2,500 & 5,100 & $-2,600$ & -51.0 \\
\hline 26 & WASCO & 23,400 & 27,900 & $-4,500$ & -16.1 \\
\hline 2 & WASHINGTON & 168,200 & 86,700 & 81,500 & 94.1 \\
\hline - & WHEELER & D & $D$ & $\overline{-}$ & \\
\hline 12 & YAMHILL & 25,900 & 19,100 & 6,800 & 35.6 \\
\hline
\end{tabular}

$D=$ Information withheld to avoid disclosure for individual firms. $Z=$ Less than $\$ 50,000$.

Source: U.S. Department of Commerce, Bureau of the Census, Census of Manufactures: 1963 and 1967 (Washington: U.S. Government Printing office). Calculations by the author. 
TABLE VIII

PER CENT GROWTH IN RETAIL SALES IN OREGON COUNTIES, $1963-1967$ (Thousands of Dollars)

\begin{tabular}{|c|c|c|c|c|c|}
\hline RANK & COUNTY & 1967 & 1963 & CHANGE & $\%$ CHANGE \\
\hline 1 & BAKER & 29,788 & 20,667 & 9,121 & 44.1 \\
\hline 9 & BENTON & 64,370 & 49,185 & 15,185 & 30.9 \\
\hline 4 & CLACKAMAS & 167,131 & 122,227 & 44,904 & 36.7 \\
\hline 12 & CLATSOP & 48,580 & 38,185 & 10,395 & 27.2 \\
\hline 2 & COLUMB IA & 29,455 & 20,833 & 8,622 & 41.4 \\
\hline 26 & coOs & 84,837 & 74,660 & 10,177 & 13.6 \\
\hline 32 & CROOK & 11,876 & 11,849 & 30 & 0.3 \\
\hline 30 & CURRY & 17,303 & 16,911 & 392 & 2.3 \\
\hline 18 & DESCHUTES & 53,275 & 43,861 & $9, \overline{414}$ & 21.4 \\
\hline 27 & DOUGLAS & 92,035 & 82,586 & 9,449 & 11.4 \\
\hline 31 & GILLIAM & 5,324 & 5,218 & 106 & 2.0 \\
\hline 16 & GRANT & 10,612 & 8,502 & 2,110 & 24. \\
\hline 7 & HARNEY & 12,913 & 9,692 & 3,221 & 33. \\
\hline 21 & HOOD RIVER & 22,891 & 19,377 & 3,514 & 18.1 \\
\hline 13 & JACKSON & 152,786 & 120,645 & 32,141 & 26.6 \\
\hline 33 & JEFFERSON & 16,611 & 16,582 & 29 & 0.2 \\
\hline 25 & JOSEPHINE & 55,439 & 48,586 & 6,853 & 14.1 \\
\hline 28 & KLAMATH & 83,549 & 75,009 & 8,540 & 11.4 \\
\hline 19 & LAKE & 13,601 & 11,299 & 2,302 & 20.4 \\
\hline 20 & LANE & 316,281 & 267,049 & 49,232 & 18.4 \\
\hline 17 & LINCOLN & 39,485 & 31,833 & 7,652 & 24.0 \\
\hline 10 & LINN & 99,389 & 78,056 & 21,333 & 27.3 \\
\hline 22 & MALHEUR & 42,556 & 36,490 & 6,066 & 16.6 \\
\hline 8 & MARION & 254,054 & 191,262 & 62,792 & 32.8 \\
\hline 34 & MORROW & 6,803 & 6,966 & -163 & -2.3 \\
\hline 11 & MULTNOMAH & $1,161,226$ & 912,442 & 248,784 & 27.3 \\
\hline 15 & POLK & 29,718 & 23,799 & 5,919 & 24.9 \\
\hline 36 & SHERMAN & 2,465 & 2,894 & -429 & -14.8 \\
\hline 23 & TILLAMOOK & 23,209 & 19,995 & 3,214 & 16.0 \\
\hline 14 & UMATILLA & 83,149 & 65,952 & 17,197 & 26. \\
\hline 6 & UNION & 29,881 & 22,104 & 7,777 & 35. \\
\hline 3 & WALLOWA & 8,554 & 6,145 & 2,409 & 39. \\
\hline 24 & WASCO & 42,927 & 37.386 & 5,541 & 14. \\
\hline 5 & WASHINGTON & 187,338 & 138,617 & 48,721 & 35.2 \\
\hline 35 & WHEELER & 1,584 & 1,814 & -230 & -12.7 \\
\hline 29 & YAMHILL & 45,906 & 40,659 & 5,247 & 11.3 \\
\hline
\end{tabular}

Source: U.S. Department of Commerce, Bureau of the Census, Census of Business, Retail Trade: 1963 and 1967 (Washington: U.S. Government Printing Office). Calculations by the author. 
TABLE IX

\section{ANNUAL AVERAGE TOTAL UNEMPLOYMENT RATES \\ BY COUNTY OR LABOR MARKET AREAS \\ $1962-1971$}

COUNTY OR

LABOR MAR- $10-y r$. RANK KET AREA $19621963196419651966 \quad 1967 \quad 1968196919701971$ Ave.

\begin{tabular}{|c|c|c|c|c|c|c|c|c|c|c|c|c|}
\hline 8 & KER & 8.6 & 6.2 & 5.3 & 5.0 & 3.8 & 4.9 & 4.8 & 5.4 & 7.1 & 6.4 & \\
\hline 2 & ENTON & 4. & & & 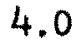 & 3.8 & 4. & 3.7 & 3.9 & 4.9 & 5.2 & \\
\hline 7 & ELATSOP & 7 & 8 & 6. & & & & 5.4 & & 6.2 & & \\
\hline & COLUN & & 7 & & & 2 & & .4 & 5.4 & 7.2 & 7.4 & \\
\hline & coos & & & & & & & 6.9 & 7.4 & & 9.1 & \\
\hline & CROOK & & & & & & & 4.6 & & & & \\
\hline & CURRY & & & & & & & & 7.4 & & & \\
\hline & DESCHUTES & & & & & & & & & 7.2 & & \\
\hline & DOUC & & & & & & & & 6.4 & & & \\
\hline 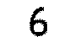 & GIL & & & & & & & & 5.4 & & & \\
\hline 8 & GRAI & & & 7. & 6. & & & & 4.5 & & & \\
\hline 1 & HARNEY & 4. & 3. & & 3 & & 3 & 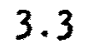 & 3 & 5.2 & 1 & \\
\hline Q & HOOD RIVER & 9 & & & & & & & & 1 & 8.4 & \\
\hline 0 & JACKSON & & & & & & & & & & 7.6 & \\
\hline & JEFFERSỌN & 5. & & & & & 7.2 & & 5.2 & 8.0 & 8.0 & \\
\hline & JOSEPHINE & & & & 8 & & & & 10.7 & 12.2 & 11.4 & \\
\hline 9 & KLAMATH & & 6 & & & & & & & & & \\
\hline 8 & LAKE & & & & & & & & & & & \\
\hline 7 & LANE & & 5 & & 4 & & & & & 7 & 7 & \\
\hline 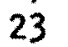 & OLN & & 6 & & 6 & & & & & & & \\
\hline & LINN & & 5 & 5 & 5 & & & & & $7 \cdot 3$ & 7 & \\
\hline & MALHEUR LMA & & & & & & & & & & 6.2 & \\
\hline 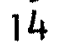 & MORROW & & & & & & & 4.1 & & 6.8 & 7.9 & \\
\hline 2 & $\begin{array}{l}\text { PORTLAND } \\
\text { LMA }\end{array}$ & & & & & & & & & & & \\
\hline & SALEM LMA & & 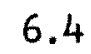 & & & & & & & & & \\
\hline & $\begin{array}{l}\text { SHE } \\
\text { WAS }\end{array}$ & & 7. & & & & & & & .8 & * & \\
\hline & AMOOK & & 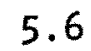 & & & & & & & 5 & 7.2 & \\
\hline & TILLA & & 6 & & & & & & & 0.3 & 1.2 & \\
\hline 4 & & & & & & & & & & .8 & 0.3 & \\
\hline 25 & WALLOWA & & & & & & & 6.4 & & 7.5 & 9.5 & \\
\hline 7 & HEELER & & 7. & 6.2 & & & 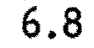 & 6.0 & & 7.5 & 7.6 & \\
\hline & YAMHILL. & 10 & & & & & - & 6.5 & 6.4 & 9.8 & 9.8 & \\
\hline
\end{tabular}

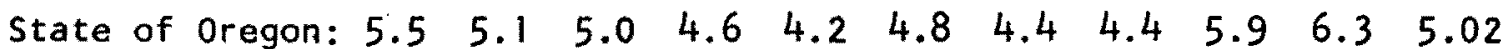

Source: Compiled at the request of the author by the Research and Statistics Department, Oregon Employment Division: July 28, 1972. 
TABLE $X$

COMPOSITE OF RANKS

RANK COUNTY QUARTILE \#1 \#2 \#3 \#4 \#5 \#6 \#7 \#8 \#9

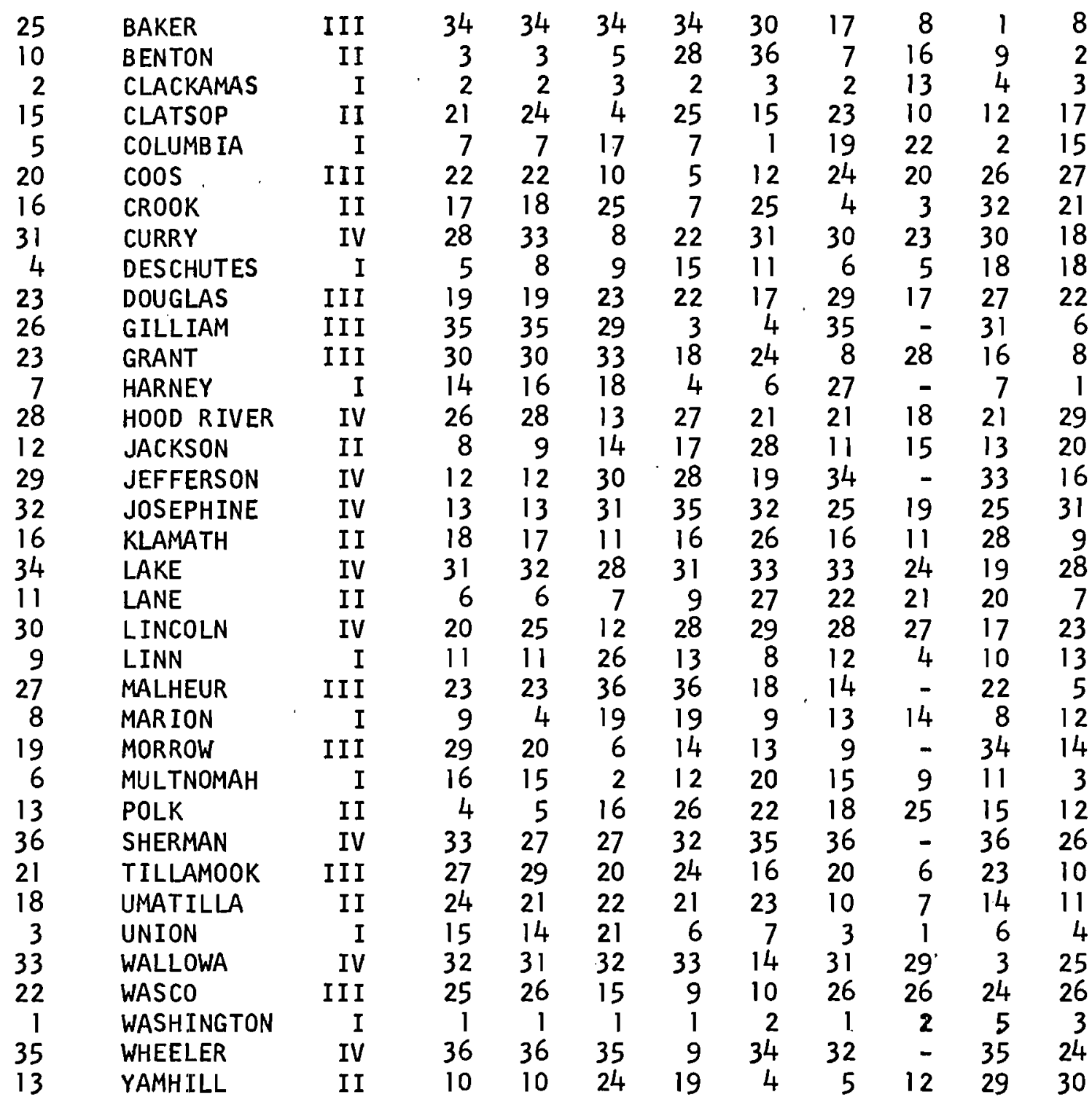

1. \% Population Growth, 1960 - 1970.

2. \% Growth in 20-49 Age Group, 1960 - 1970.

3. Per Capita Income, 1969.

4. \% Persons Below Poverty Livel of Income, 1969.

5. \% Increase in Median Income, Families \& Unrelated Individuals, 1959 - 1969.

6. \% Growth in Employment, 1965 - 1971.

7. \% Increase, Value Added by Manufacture, 1963 - 1967.

8. \% Growth in Retail Sales, 1963 - 1967.

9. Average Total Unemployment Rates, 1962 - 1971. 
FIGURE 2

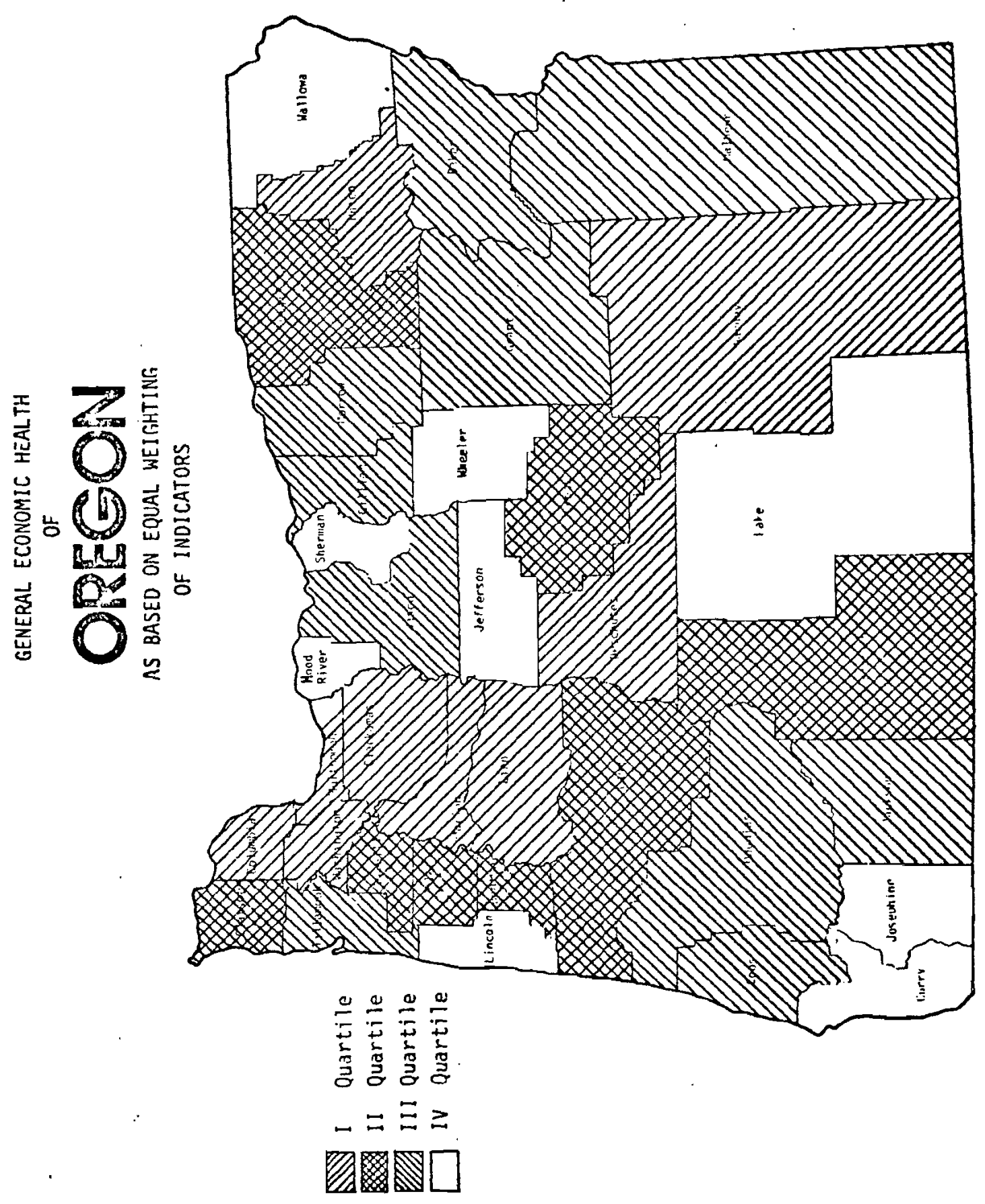


TYPES OF SUBSIDIES AND THEIR EFFECTS ON RESOURCE ALLOCATION

With this preliminary analysis of the economic and social benefits that might be sought for Oregon through an industrial subsidy program; we can now consider what types of subsidies might be employed and at tempt to evaluate their effects. For illustrative purposes, an analysis cited by Richardson will be useful. 12

The model he examines was developed by G. H. Borts to show the relative advantages of three different kinds of subsidy: labor, capital and prices. The model measures the cost of a subsidy as a social cost, defined as the output foregone by diverting capital from its most productive use, rather than a monetary cost which is simply a transfer. The aim is to consider the most efficient short-run method of securing. full employment within a region by comparing the social rate of return from the three types of subsidy. The model assumes an inelastic supply curve for labor, treating it as a fixed resource, and a perfectly elastic supply curve for capital, which makes this the variable factor.

The model also asșumes that the marginal revenue product of labor in the region's competitive industry declines due to a decrease in the: price of that industry's output, but that wages are rigid and fail to decline to an equilibrium level. This causes the industry to leave the region, which then becomes characterized by a discrepancy between the

12 Richardson, op. cit., pp. 405-409. 
private and social costs of labor. - The private cost is the fixed wage, while the social cost is the productivity of labor in the industry in competitive equilibrium.

Borts considers three forms of Intervention to allevlate this discrepancy: 1) a wage subsidy, whereby the government subsidizes employers the difference between the old and new marginal product of labor; 2) a capital subsidy, with which employers are paid the difference between the competitive rate of return on investment and the return earned after the price decline (through low Interest loans, tax relief or cheap site and factory rents); and 3) a price subsidy, where the industry's output is subsidized by payment of the-difference between the old and the new price of output.

The analysis estimates the social rate of return from each of. these policies. Since it was assumed that industry would leave the region without subsidies, then the social return to the subsidy is the full output of that industry. The cost to the subsidy is the output lost by transferring mobile capital resources into the industry, "measured by the output sacrificed in other uses with a higher productivity of capital: (opportunity cost).

Borts concludes that the wage subsidy is" the best. of the three policies in terms of social return: Seeking full employment as the objective, a direct wage subsidy encourages maximum utilization of the labor resource by decreasing the direct labor cost to the industry. The higher the elasticity of substitution between labor and capital, the greater the returns from this policy, as industry will be encouraged to employ more labor in relation to its capital expenditures. This would always be true except in the case where a fixed labor-capital ratio. 
exists and the percentage decline in output price is greater than the share paid to labor.

If capital subsidies are used, their effect is to increase the capital-labor ratio in order to increase the marginal physical output of labor. The price decline would then be offset by this increase in the marginal physical output of labor while the marginal revenue product of labor remains unchanged. This allows the industry to pay the original wage while earning the original rate of return to its own capital investment. This, in effect, would result in the same social return as the wage subsidy but at the higher cost of transferring more capital out of other, more productive uses.

With price subsidies, both initial output and capital are left unchanged. This also will permit the industry to retain its original employment level. It does, so, however, through an implied artificial rise in the value productivity of capital created by subsidizing the price of output. Again, the capital, resource is over valued, resulting. in higher social costs due to the transfer of capital from more productive uses.

It would appear that one of the primary determinants of the effectiveness of these three policy alternatives is the substitutability of labor and capital. If a fixed ratio exists, then capital and price subsidies become relatively more attractive: But as the substitut-. ability of labor for capital increases; then the wage subsidy will produce a higher return by withdrawing less capital from other uses." This will result in a.higher level of total output for the region. While this type of analysis is somewhat theoretical, especially in terms of the practical alternatives available to public agencies, 
it does produce some useful insights into how different types of subsidies will vary in their effects on regional development. In particular, it shows that there is more to consider than the employment and output gained by the subsidized plants.

While the Borts model may be limited in its applicability to Oregon because of its structural assumptions, some comparisons can still be made. For example, the assumption of a price decline for the region's industrial output can be compared to the historical situation of agriculture where there has been a price decline relative to other industries. That condition, along with the increased substitutability of capital for labor in agriculture and a rising marginal revenue product of capital over labor, would create a situation very comparable to that described by Borts. If we can also assume imperfect mobility of labor in the agricultural areas, then the effect would be a reduction in income levels along with rising unemployment. As seen in the last chapter, this is the condition that prevails in much of rural oregon.

The industrial subsidy programs being prescribed to correct Oregon's imbalances would generally fall into the category of capital subsidies. It is assumed that by the vehicle of expanding regional productive capacity and output, the variety of economic and social goals, such as population shifts and employment of surplus labor, can be achieved. As mentioned earlier, however, such policies will have an effect on resource allocations and there is some question as to whether an efficient allocation can be achieved which will produce the desired objectives. This problem will now be examined in greater detail.

As stated earlier, a major problem in the resource allocation question relates to the geographical area in which the benefits of the 
subsidy program are measured. One criticism of such programs is that by influencing a firm to locate in one place rather than another, there is no real net gain in output to compensate for the public investment and economic shocks caused by competitive bidding for the plant. According to this hypothesis, a plant will be built for a specific production capacity, determined by the nature of the market and the firm's competitive position in that market, so regardless of where it is built the output will be the same. Under this hypothesis, industrial subsidy programs have been referred to as the "zero-sum game".

The type of criticism expressed in the zero-sum hypothes is results from broadening the scope of analysis from the local level to a more regional or national overview. The complaint lodged against community efforts to attract industry through financial and tax inducements is that the practice is self-defeating in the sense that it induces other communities to do likewise. The alleged result of this rivalry is that one community's gain is offset by another's loss.

This zero-sum concept is also modified somewhat by the claim that the loss of a plant to one community, with its resultant effects of throwing people out of work and decreasing income flows, is too great a price to pay for some other community to gain a new plant. Therefore, whether we are considering new plants or relocations, the concept of industrial subsidies is viewed as producing either zero or negative results when considered in a broad perspective.

This criticism, if it is valid, could have an important bearing on policy decisions in Oregon. Even if a purely self-interest policy should be adopted, so that the negative effects of industrial subsidies in other areas of the country are ignored, there would exist the 
possibility that other states would adopt a sim!lar course and Induce oregon firms to leave tho state. "The summary of programs given in the appendix indicates that this is already being done by most other states, however. Stili, there might also exist the possibility that a local subsidy program in Oregon would produce the effect of relocating firms within the state, in which case the state government would have to consider both the positive and negative effects of those programs. The subject then becomes a serious consideration in assessing the political, as well as the economic and social, implications of subsidy programs.

The zero-sum concept, and its criticisms, was described by the example of a case history which occurred in 1961. According to one report, ${ }^{13}$ the management of the Norge Division of the Borg-Warner Corporation in Muskegan, Michigan, suddenly announced plans to close its plant there. No advance notice was given to the plant's 1400 workers, who had spent an average of 15 years working for the company. Almost 900 of these workers were over 40 years old, while 235 were over 55 years of age--an age group which normally has great difficulty finding new jobs.

At the same time this announcement was made in Muskegan; which was already designated a labor surplus area, the same firm--Norge Div-. ision of Borg-Warner--announced that it would build a new manufacturing plant at Greenwood, Arkansas, 700 miles away. The new, $\$ 7.5$ million. facility would be financed by the proceeds from the sale of tax-free

\section{3} Frank L. Fernback, "Subsidized Plant Migration," American Federationist, Vol. 73, July, 1966, pp. 8-12. 
municipal bonds. The report soundly condemned this and all other forms of subsidized plant migration.

The report failed to consider any reasons why the plant at Muskegan was being closed or to explore any reasons why the firm was relocating its facility. It assumed that the cost advantages of the subsidy were the only determining factor.

Nonetheless, this kind of example warrants a further look into the net effects of the induced location of industry. Even where subsidies are used to attract new plants rather than relocations, the criticism that a plant gained in one area is offset by that plant not being gained in another area is worthy of consideration.

An examination into this question is provided by Rinehart and Laird. 14 They based their analysis on the assumption that full-employment communities will make less use of industrial subsidies than will depressed communities with labor surpluses. State programs which seek to shift industrial investment to depressed areas would normally fit such an assumption. The effect of the subsidies, then will be to increase the net flow of capital into the labor-surplus (capital-scarce) regions. More capital will become available in the region than would otherwise be the case as new firms and branch plants are attracted. This means that for the region as a whole, the competition for industry does not have a cancelling-out effect, even if it may appear to do so for individual communities within the region.

The study also considers some of the justification criteria 14. R. Rinehart and W. E. Laird, "Community Inducements to Industry and the Zero-Sum Game," Scottish Journal of Political Economy, Vol. 19, (February, 1972), 73-90. 
mentioned by Richardson, including the possibility that on a regional level the shift in capital flows may leave overall levels of employment and income unchanged, but finds that: ". . the benign zero-sum outcome allows a broader range of choice for individual preferences regarding location and life-style and in that respect promotes an increase in social welfare." 15

Another relevant finding, from the aspect of state policies and goals, is that an increased capital inflow into underemployment regions may slow the forced migration into the larger urban centers and thereby promote an overall pattern of resource allocation which will make the interrelated problems of congestion and pollution more amenable to solution. These last two considerations were among the specific goals stated in the justification for a subsidy program in Oregon by the Senate Task Force on Economic Development.

By looking at the problem in this manner, and assuming that subsidies are, in fact, used to promote capital flows to areas of need, it would appear that industrial inducements do produce a net overall gain, at least in terms of their social benefits. Thus, the zero-sum hypothesis, that one plant cancels out another, can be questioned. However, there is still the economic question of whether the industrial subsidy program would result in reallocation of resources to less efficient uses, thereby lowering overall levels of output. This question is compounded by the further argument that the new, subsidized firm will compete for inputs locally to the degree that its subsidies enable it to flourish. Even where local unemployment is considerable before the new plant is

$$
\text { 15 Ib id, p. } 81
$$


attracted, already employed resources will be used to some degree and even the use of formerly unemployed factors of production will affect the price of factors employed by other firms. 16

This criticism has been extended to include the theory that the misallocation of resources resulting from subsidizing industrial locations in depressed areas actually leads to a net decrease in the economic level of the region. The bas is of this argument is that resources are less productive in the depressed areas, which is why they are characterized by higher unemployment in the first place.

Peter Drucker makes this point when he criticizes Britain's policies of subsidizing industrial migration to lass developed areas. He states that:

The depressed areas policy in Great Britain dates back to the twenties. In all that time it has not restored to economic health one single 'depressed area.' But it has effectively penalized the shift of labor to areas of higher productivity, higher wages and better jobs. It has thereby slowed growth in the healthy regions. Yet whenever it is realized that the 'depressed areas' are still depressed, the budget goes up. That the Swedes, faced with a similar problem, actually got rid of their 'depressed areas' by subsidizing migration of labor out of them rather than, as the British do, migration of inefficient industry into them, is well known in England. But it has made no impression on government or public in Britain. 17

This pessimistic view is limited, of course, by his reference to "inefficient" industries. If the subsidies represent an offset against other higher cost factors attendant to the location, then the concept of inefficiency cannot be assumed. The next chapter will review the types of companies most frequently attracted by industrial subsidies and, at least in the American case studies, document that they cannot normally 17 Peter Drucker, The Age of Discontinuity (New York: Harper \& Row,
p. 228 1969), p. 228 
be classified as inefficient.

There is another reason, also, why the British experience is not valid for estimating resource al location effects from subsidy programs in the United States. While British programs provide positive incentives for industrial locations to depressed areas, including the construction of low-cost facilities; their system suppliments this with disincentives for location. in developed areas. The primary disincentive is the requirement that firms obtain an Industrial Development Certificate (IDC) as a precondition to their being permitted to establish a new facility. By denying issuance of an IOC in a developed area, the Board of Trade can force the firm to either abandon its plans or locate in an inefficient area. 18

The result of this program has been less than satisfactory for the firms as well as for the depressed regions. According to the Board of Trade:

. it is reasonable to suppose that the large majority of firms which have gone to an unemployment area as tenants of Board of Trade factories, or with financial assistance, would not have done so had they been able to get an IOC in the place of their choice. No doubt firms urgently needing finance would be ready to set up on a development district in return for financial assistance, but these are in general 19 not the firms that are likely to give continuing employment. 19

It would appear that attaching disincentives to a subsidy program creates justifiable criticism of both the effectiveness of the program and its impact upon the efficiency of resource allocation. Even the social benefits of such a program might be negated if the result is the

18 Wesley C. Ballaine, "British Experience in Influencing Location of Industry," Western Economic Journal, Vol. IV (Summer, 1966), 237-46.

19. The Policy and Practice of the British Government for Deal ing With Local Unemployment (London: Board of Trade, 1960), p. 12. 
inefficient location of marginal firms which fail to give permanent employment. 20

Rather than considering generalizations about resource allocations, it would be better to review the type of subsidy employed and surrounding oconomic conditions in detormining the resourco allocation offocts in a particular subsidy situation. Regarding the labor resource, for example, different effects are shown for situations where the labor is mobile versus those where it is immobile. In Gray's analysis of these situations, he observed that:

With respect to community financed subsidies to industry, the following can generally be concluded:

1. If labor is immobile with respect to wages, employment and real income in the economy as a whole will be expanded in a manner consistent with the requirements for opt imum resource allocation regardless of the financing techniques employed by the community.

2. If labor is mobile with respect to wages, employment and income will rise, but the spatial distribution of resources will be incopsistent with the requirements for optimum resource al location.

Gray further maintains that while workers shift locations in order to obtain employment, the greatest part of structural unemployment in the United States consists of wage-immobile workers--redundant farmers and women in areas of low female labor force participation rates. Thus, he says that: ". . it is conceivable that the majority of industrial

20

An example would be a case in Roseburg, Oregon, where a local development corporation was established to sell stock to finance a mobile home manufacturing plant. The plant closed after less than two years operation, leaving the local stockholders to carry the costs of the empty facility and returning unemployment to a high level.

${ }^{21}$ Ralph Gray, "Industrial Development Subsidies and Efficiency in Resource Al location," National Tax Journal, Vol. 17, (June, 1964), 170. 
development subsidies--past, present and future--have improved overall resource allocation." 22

Gray recognizes that a subsidy program could also be used to encourage outmigration as a means to overcome rigidities in labor immobility. He points out, however, that there are economic and social costs attached to this, also. He claims that the poverty and resulting social problems of migrants from the nation's labor-surplus areas are carried with them when they relocate into a labor-scarce area. This has the effect of increasing the costs of providing social overhead in the urban areas.

These considerations are discussed by Morss in a different manner. ${ }^{23}$ He acknowledges Gray's argument but says that the competitive market for new plants is similar to the competitive market for labor resources. Thus, in a competitive subsidy situation, the plant will locate where it has the highest value to the subsidizing community. This will produce a net benefit regardless of whether the labor moves with the plant or is recruited from the local ranks of unemployment.

There is also reason to doubt the assumption that subsidized alterations in resource allocations means moving away from an optimum free market condition. Cumberland and Van Beek observed that there are many economic and non-economic barriers which prevent the free flow of resources whether subsidization is practiced or not. ${ }^{24}$ The discriminate 22 Ib id, p. 171

${ }^{23}$ Elliott R. Morss, "The Potentials of Competitive Subsidization," Land Economics, Vol. 63 (May, 1966), pp. 161-169.

$24 \mathrm{~J}$. H. Cumberland and Frits Van Beek, "Regional. Economic Development Objectives and Subsidization of Local Industry, "Land Economics, Vol. 63 (August, 1967), p. 257. 
use of subsidies may act to remove these barriers: In any case, they conclude, it would be difficult to support the contention that an "optimal" allocation will occur, if subsidies are not employed.

Richardson makes the same point." He observes that technological changes, variations in factor costs, etc.; will tend to alter the average cost relationships between various locations over time. He states that: "Location decisions based on present data and/or on" assumptions that the present can be extrapolated into the future will be' unlikely to maximize profits in the long run." 25 He therefore concludes" that:

. . it is unlikely that many firms will make sophisticated calculations in conjunction with crystal-gazing. It is much more probable that firms, in full recognition of future changes. in spatial costs and prices and the difficulties of measuring external economies, will not go to extreme lengths to find the -most profitable location, but instead will opt for a location that seems viable in the long run and rely on increasing effi-. ciency in other respects to raise their profitability. 26

So the concept of a single, optimum location is not always applied when siting new plants. Richardson recognizes that "natural" locations. are not always the most efficient and that technical efficiencies can make a variety of locations nearly identical-in average costs. This is particularly true when certain factor resources are immobile so that optimum efficiencies are not attained. In this case, there may be as " much case for subsidizing movement of capital into a region as for subsidizing movement of labor out of it. The test of efficiency would be to determine, whether the marginal revenue product of the immobile

$$
\begin{aligned}
& 25_{\text {Richardson, op cit., p. }} 92 . \\
& { }^{26} \text { Ibid }
\end{aligned}
$$


resource (labor) is greater than the marginal revenue product of the mobile resource (capital) in the alternative use from which it is diverted. Richardson introduces this concept of opportunity cost as a principal criterion for judging subsidy policies.

Richardson also suggests as a criterion that relocations of firms should be evaluated in terms of future income growth in both the exporting and receiving regions and in terms of demonstration effects and the generation of external economies rather than simply in terms of the number of jobs created and their cost. Applying these criteria will determine if, on net balance, a capital subsidy policy can be justified in economic terms.

The question of efficiency in resource allocation does not necessarily depend upon an assumption of optimality under free market conditions, however. There is a presumption in subsidy programs that the subsidy will induce a firm to locate in an area where it otherwise would not go. Therefore, a reallocation would occur regardless of whether the freely chosen location would be an optimum. So the argument just proposed would affect the degree of efficiency alterations, but not necessarily the substance of the criticisms.

Again, this question can be viewed from different perspectives. We have already seen that the resource allocation question produces different results when viewed at the national (general) level versus the local (specific) situation, and that in some cases it may even be possible to show that there is a conflict of interest at these two levels. Within the local area there are also some problems that need to be considered, in addition to those already mentioned. For example, some regional development programs seek as their objective the shift of 
industry from urban to rural places that are characterized by an agricultural economy. This is one of the stated objectives of the Oregon. proposals. Yet the location of industry in such an area will have the two adverse effects of increasing wages and land costs for the farmer. one study of this situation ${ }^{27}$ cited it as a serious problem for the small farmer. It noted that farmers often rely on seasonal and part-time workers who may become unavailable as full-time factory jobs are created. While the overall productivity of labor in the area may be increased, it is done so at the expense of an important sector of the rural economy. This question of altering resource allocations, then, is a complex one from the standpoint of state development policy. There are many externalities involved when shifts are made. This is true, however, whether those shifts are induced by subsidies or occur without them. There are also external effects of leaving a depressed area to decline even further. It is reasonable to assume, however, that companies using subsidies will have to be convinced that there are underemployed resources available which can be used productively. Where this is the case, the effect of the subsidy must be to increase the overall efficiency of those resources, at least on the local level. It may be that those resources could be even more productive if moved to another area, but this also involves costs. Each situation, then, must be reviewed in detail to determine the optimum policy in terms of overall objectives.

The preceding analysis has indicated that the types of subsidies employed in an industrial inducement program will have varying effects

27 John T. Scott, Jr., "Economic Impact of Industrialization on Rural Areas," Illinois Business Review, Vol. 25, No. 8 (September, 1968). pp. 6-8. 
upon the measured results of the program, primarily because of the different ways they alter resource allocations. The efficiency question in reallocating resources has also been examined. There are, however, two additional factors that will have a major bearing on the results of the program; the economic characteristics of the region, and the types of firms subsidized. These factors.will be analyzed in the last chapter when an examination is made into the possible results that can be expected from a subsidy program in Oregon. Before this is done, though, some useful preliminary information can be developed by looking at empirical data on how subsidy programs actually have worked in other. areas: This will be the subject of the next chapter. 


\section{CHAPTER IV}

\section{INFLUENCE OF INDUSTRIAL SUBSIDIES ON LOCATION DECISIONS}

The question of whether or not industrial incentives can alter geographical patterns of economic activity would be moot if such devises lacked influence upon the primary investment decisions of companies seeking new plant sites. The wide use of incentives, supported by an extensive body of surveys and evaluations, suggests that a significant degree of influence does exist. However: that influence varies by the type of incentive used and the prevalence of other criteria in the investment decision. Analysis of these considerations will be presented in this chapter.

Before the empirical evidence is given, however, it will be useful: to discuss some theoretical concepts of industrial location and how subsidies function to alter the location decision of a firm." This wili......... help to put such incentives into perspective with other location criteria. An analysis of optimal location theory and the influence of subsidies is given by Richardson. ${ }^{28}$ In general terms, the optitial geo-........ graphic location for a firm will be where the combined factor inputs in the production and marketing processes will produce the lowest costs per unit of product sold in the market: Since it would be improbable that the lowest costs for all factors would be found in a single location, the search for the optimal location necessarily requires weighing higher ${ }^{28}$ Richardson, op. cit., p. 92 
costs for some factors versus lower costs for others at a variety of. possible locations. An area with low labor costs, for example, might. have high transportation costs for "delivered raw materials or finished goods shipped to market; or low raw material costs may be associated with high costs for land and capital.

For each of the possible locations surveyed, these factor costs will combine to produce an average cost per unit of projected output. When all of these individual average costs are charted, the result is an average cost curve which covers the entire range of al ternative locations. The low point on this U-shaped curve will identify the optimal location in terms of lowest average cost.

To a firm in a competitive industry, where the price per unit of product sold is fixed by the market; the location. offering the lowest average cost will also offer maximum profits (assuming average revenues. are greater than average costs). So the average cost determination establishes, the location for a firm motivated by profit maximization. While computer analys is makes such determination possible, the result is a static model rather than one which predicts average costs over the life of the plant. As previously noted, long-term efficiency considerations will modify the lowest-average-cost determination to some degree. This qualification, then, will tend to reduce the probability that the firm will find only one site which will satisfy its locational requirements. Theoretically, any site within the range of profitability where average costs are lower than average revenues may be considered by the firm which is seeking profit maximization. Excluded from consideration, however, will be those locations outside the range where profits would be made. 
In this framework, it can be seen how incentives work to influence the locational decision of the firm. Richardson's diagram, 29 modified slightly and reproduced here as Figúre 3 , shows the U-shaped average cost curve for the range of possible locations, measured spatially, along with the horizontal average revenue curve which is fixed by the market for all locations. The least cost location is identified as $Z$, while Mx and My represent the spatial limits to profitability.

\section{FIGURE. 3}

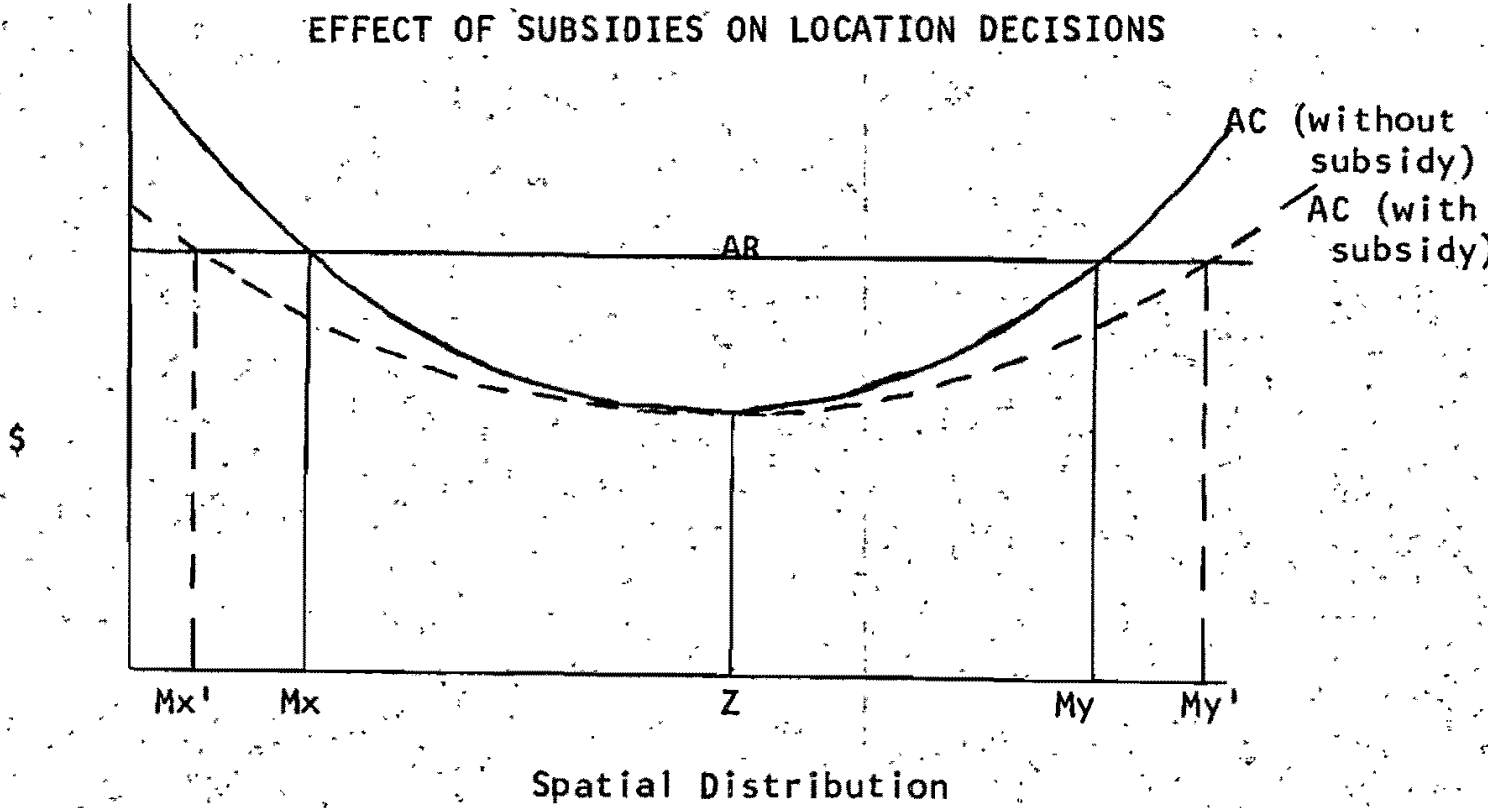

The effect of the subsidy, whether it is offered as a tax reduction, a capital cost advantage or some other form of direct cost subsidy, is to reduce average costs, thus broadening the spatial range of profitable locations. By applying the subsidy discriminately to areas which would not normally be able to attract industry, it becomes possible to extend the boundaries of the margin of profitability to include those ${ }^{29}$ Ib id., , P. 66. 
areas.

The example shown on the diagram assumes a graduated subsidy program, with no subsidies offered at the optimum location and increased incentives becoming available as the firm departs farther from that optimum. In this case, rather than the average cost curve being shifted downward to widen its spatial limits. of profitable operations, the entire shape of the curve is altered. The spatial limits of profitability are widened, but the average costs at the optimum location. remain the same. The new limits to profitability now become $M x^{\prime}$ and My.'.

This simplified model can be directly applied to the three types of subsidies analyzed in the last chapter. There.it was assumed that average costs remained constant but that prices declined. "This would ". have the effect of lowering the average revenue 1 ine and narrowing the spatial range of profitable operations.

By providing a wage or capital subsidy, the average cost curve, for the firm would be shifted downward to return to the original spatial relationship, only at lower cost and price levels. The difference between actual average costs and the average costs for the firm would be the direct cost of the subsidy.

In the case of a price subsidy, average costs would remain the same but the revenue line would be shifted upward again to its original level, with the difference between the market price and the revenue. received by the firm being the direct cost of the subsidy.

The most common form of subsidies, and those which will be specifically analyzed in this chapter, are financial incentives and tax reductions. Both of these act to lower the average costs for the firm 
and would therefore affect the location decision in a way similar to that outlined above for wage and capital subsidies.

Richardson also includes an example of how the reverse of subsidies, disincentives, can be used to deflect new firms away from areas where new growth may be undesirable. This could be done through the imposition of a special tax which would raise average costs in those areas to a level above the average revenue line. Firms would then have to locate outside that area in order to make a profit:. Orie obvious problem with this alternative is that the range of profitable operations for a firm might easily extend across state or regional boundaries and such disincentives, employed within the confines of a single state, might easily have the effect of deflecting firms to profitable locations in other states rather than to depressed areas within the state imposing the disincentives: Since we are looking at policy alternatives at the single state, level, that type of program does not appear to offer practical consideration.

This analysis shows some of the theoretical implications of subsidy policies on plant location decisions. We can now look at empirical evidence to assess the effectivenes of such policies where they have been applied in regional, development programs. Specifically.; we will look at the most common forms of industrial subsidies; financial incentives and tax inducements.

\section{FINANCIAL INCENTIVES}

On the basis of published surveys, a direct corelation can be established fairly easily between financial incentives to industry and 
new plant locations. Such incentives can take various forms, including the financing of plant and equipment with tax-exempt bonds, or direct. cash grants: In any case, the effect is to lower capital costs for the firm locating in a designated area.

Programs in Canada present some of the best-documented case histories of the effects of financial incentives. Operating under the Regional Development Incentives Act, defined as: "An Act to provide incentives for the development of productive employment opportunities in regions of Canada determined to require special measures to facilitate economic expansion and social adjustment, ${ }^{30}$. the Canadian Department of Regional Economic Expansion has authorized or undertaken numerous studies to measure the effectiveness of industrial incentive programs in that country. Created by an Act of Parliament, the Regional Development Incentives Act became effective July, 1, 1969, to create new job opportunities in regions of high unemployment or slow economic growth. It replaced, earlier programs of a similar nature under the Area Develop:ment Act. Administered through the provincial governments, the plan offers no tax reductions but instead provides generous capital incentives to industry for manufacturers establishing, expanding or modernizing plants in the designated regions. Up to $\$ 12 \mathrm{million}$ per plant is available in cash grants based on capital investment in the operation, the number of jobs created and the specific location. All manufacturing. and most kinds of processing firms are eligible, excluding those engaged in initial processing in a resource-based industry, such as oil refining, 30 Regional Development Incentives Act, 1968-1969, c. 56 (Ottawa: Queen's Printer For Canada, 1969). 
pulp and newsprint. 31

One of the most thorough studies authorized under this program comes from the southern Georgia Bay region in Ontario, where an A.D.A. incentives plan was carefully scrutinized during its first two years of operation. 32 From the commencement of the incentives program in August, 1965, until the time of a questionnaire survey in August, 1967, thirty-one plants in the region reported that they had made use of the program. of these, eighteen were entirely new to the area and cited the incentives.program as their primary reason for locating there.. The. study showed, that a little over $\$ 7 \mathrm{million}$ had been granted to these firms by the end of 1968.

Direct and indirect investment generated by this program came to. more than $\$ 80 \mathrm{million}$, with the new factories accounting for $\$ 77 \mathrm{million}$ of this: It is estimated that employment: grew in the area by 27.3 percent because of this new investment, which was an increase of over. 5,000 jobs." Payrolls increased in excess of $\$ 20 \mathrm{mill}$ ion and local tax revenues grew by about $\$ 1$ million. To cite the study:

In more general terms, it (the program) effectively revolutionized almost every aspect of the economic 1 ife of the southern Georgia Bay Region, raising it from a lightly industrialized, primary producing area with little hope-for growth, to a potentially fast developing industrial region geared to the booming Ontario economy. 33

This endorsement was tempered, however, by some other facts brought out in the study. One was that the area was begining to

31 Ib id.

32 M.H. Yeates and P.E: Lloyd, Impact of Industrial Incentives: Southern Georgian Bay Region, Ontario (Ottawa: Policy Planning Branch, Department of Energy, Mines and Resources, 1968).

33 Ib id., P. 25 
experience the spread effects of growth in the Toronto area and the incentives program served as a stimulus to accelerate that spread, which seems to contradict the prior statement that the area had "little hope for growth." It was also noted that a recently-completed new highway, connecting the area with Toronto, attracted the majority of the new plants. This provided a benefit of reducing transport costs and providing easier access to a major market and freight interchange. Presumably, the program would have been less successful without this additional asset. In concluding its evaluation, the study states that: ". . the designated area was something of a special case and by no means the epitome of a depressed region. This must be clearly borne in mind in gauging the reasons for the success of the program. $11^{34}$

Studies of successful programs in other areas of Canada generally make the same kinds of qualifications. A Nova Scotia survey ${ }^{35}$ included 80 companies which had built new facilities in the 1963-1967 period, 45 of which had received financial incentives from the provincial assistance program. The total capital investment of the assisted firms was $\$ 194$ million, versus $\$ 22$ million for the 35 non-assisted firms. The survey showed that the assisted plants created direct employment of 1554 people, plus an additional 1682 jobs through backward and forward I inkages, and 2005 more through multiplier effects, for a total of 5242 jobs. of the 45 companies receiving assistance, 19 said that the influence of the incentives program had been sufficient to affect their location

$$
\begin{aligned}
& 34 \text { Ib id., P. } 65 \\
& 35 \text { Robert L. Comeau, A Study of the Impact of the Area Development } \\
& \text { Agency Program in Nova Scotia (Halifax: Dalhousie University, 1969). }
\end{aligned}
$$


choice. A larger number, however, felt that the program had exercised some influence on their development plans, either speeding up the, planned development or encouraging the firm to enlarge its plans.

When viewed in context with other investment criteria, however, this study also concluded that the inducements affected only the marginal choices and that there were other prime factors in the location decisions." It states: 'All in all, the 'natural' conditions: raw material, markets, labour and transportation appear to be the most important factors determining choice of locations."36.

A third Canadian study also confirms this conclusion. 37 After reviewing the success of the regional incentives program in attracting new investment to northwestern Ontario, the study states that:

The establishment of new, or the expansion of existing indus:try, depends upon two preconditions: (1) an initial demand for a resource from the region to start the development process, a demand emanating, usually, from outside the region; and (2) a population 'watershed' large enough to sustain the growth process once started.

These examples from Canada would indicate that financial incentives can influence companies to locate in less developed regions but only if certain other factors are available which can contribute to efficient operation. This conclusion is also made in many studies of similar programs at the federal and state levels in the United States. One American report released in 1970, for example, evaluated the influence of 42 programs of federal ass istance to reallocate the geo36 Ib id. , p. 136

37 The Northwest Ontario Regional Development Program (0ttawa: Department of Treasury and Economics, Regional Development Branch, 1969). 
graphical distribution of industrial activity. ${ }^{38}$ These programs encompassed a wide range of activities, including business loans, grants for the development of infrastructure, and manpower programs. Among the conclusions of this report was that:

The fundamental requirements of the American economic system; natural resources, labor, capital and markets, are influenced to some extent by more than forty federal programs which provide assistance to public agencies, private institutions and individuals. But the geographic impacts of these programs, in the aggregate, are modest: They are largely confined to accelerating pre-existing trends toward economic concentration in metropolitan areas or to curbing slightly prevailing trends of economic decline. 39

Several reasons were given for this limited influence, particularly that: "Broad economic forces and locational decisions of the private sector are the major determinants of geographic distribution (regionallocal) of economic development and growth."

In analyzing individual programs, however, the study found that: "Aid to business investments--including loan guarantees, subsidized loans, subsidized plant and equipment--has the greatest and most immediate effect of stimulating additional economic development. 140

It should be noted that part of the limited influence of federal programs was ascribed to administrative difficulties. The report also charged that many programs were conducted without a clearly defined objective.

Another report which looked at dispersion of industry as a national policy was conducted by the Fantus Company. In its overall assessment,

${ }^{38}$ Federal Activities Affecting Location of Economic Development, prepared for the U.S. Department of Commerce by the Center for Political Research, 1970.

$$
\begin{aligned}
& 39 \text { Ib id., p. I-1. } \\
& 40 \text { Ib id. }
\end{aligned}
$$


the report stated:

Basically, it has to be remembered that the business executive entrusted with plant location decisions will continue to seek a site which so combines all locational factors as to give the lowest cost per unit of output. . . . . And in many instances, he will be interested in incentive industrial

financing programs provided that these do not make him sacrifice or compromise his locational objectives. 41

On the national level, then, the influence of financial incentives on business investment decisions would appear to be positive only where other required conditions exist.

Perhaps of greater interest for state policy considerations, however, will be a review of other state programs in the United States. Moving from national policy to state programs, though, involves a change in emphasis. Where national efforts are primarily aimed at encouraging business investment in areas of high unemployment, most state programs, in the past, have been operated with less regard to geographic distribution to areas of need within the state. State programs for financial assistance primarily increase available credit or lower costs through subsidized interest rates to firms locating anywhere within the state. Such programs, then, create a high degree of competition between states with limited regard for altering development patterns or dispersing growth to non-metropolitan areas.

In fact, the multiplicity of location factors discussed above has largely resulted in state financial incentive programs being used to further concentrate economic activities. The competitive nature of such programs has encouraged state agencies to apply their incentives in

${ }^{41}$ Fantus Company, How Much Can We Influence The Growth of Industry in Rural Areas, prepared for the U.S. Department of Agriculture, (October, 1970), pp. 36-37. 
locations which can offer the variety of location requisites which form the principal basis for investment decisions.

The Fantus report, previously cited, mentions the example of Kentucky which found that it could measurably increase its overall state growth rate by obtaining a larger share of national industrial growth. The state accomplished this by: ". . . concentrating on those location opportunities for which the greatest advantage to industry could be demonstrated. $11^{42}$

When state financial incentives are used in this manner, it is in

relatively easy to correlate the incentives with new plant investment by the use of empirical evidence. It is more difficult; however, to draw conclusions from that correlation as to the strength of the incentives program in the final location decision when weighed against other factors. A firm, for example, may consider a new plant location in any one of several states offering industrial. revenue bonds. While the final decision may be made on the basis of some-other criterion, the availability of revenue bonds to build the plant would be cited as a causal factor regardless of which state finally received the investment. While it is easy to overstate the importance of financial incentives as a causal factor in investment decisions, there is evidence that their existence does contribute to the location of industry between states. Part of the reason for this lies in the nature of the companies that use such incentives and the expectations of those firms. A study of industrial bond financing in Alabama revealed that whereas 65 percent of the firms using this form of assistance in Alabama had considered.

42 Ib id. ; p. 33 
alternative locations in other states, only 47 percent of the firms using conventional financing did so. ${ }^{43}$ This implies that assisted companies investigated a larger number of plant locations and may have been seeking the "best deal."

In doing so; however, the industrial bonds were considered very important. Of the $54 \mathrm{firms}$ in the survey that had used them, 38 ranked this factor no lower than third in order of importance among all location factors, making it the most frequently mentioned of all factors. In analyzing this finding, the study states:

Considering that about one-sixth of all new plants and plant expansions in Alabama have been financed with industrial bonds, it would appear that such bonds are a decisive marginal factor for as many as 10 percent of the firms locating plant facilities in Alabama. This is a relatively small proportion of the total number of firms, but from the standpoint of capital investment 44 and employment, their influence is scarcely 'inconsequential'. 44

The study reinforces this last statement by revealing that the 38 firms which gave a high ranking to industrial bonds had invested about $\$ 318,052,000$ in manufacturing facilities and had an associated employment of 7,293 persons. This translates into an average investment of $\$ 43,500$ in plant facilities per job created--an investment figure substantially above the United States average at that time (1963) of $\$ 21,500$.

This finding, if generally supported in other areas, would indicate that financial incentives are most important to firms in capital intensive industries. This would seem logical since for these firms

${ }^{43}$ A. A. Thompson, "Business Experience With Industrial Aid Bonds as a Source of External Financing: Some Empirical Evidence," California Management Review. (Winter, 1970), p. 30.

44 Ibid., p. 31. 
the differential costs of financing $p$ lant and equipment at varying interest rate levels would be significantly more important than for a company with relatively low capital requirements. A brief exercise will show how a firm can realizo substantial cost reductions through tho lower intorest ratos available from tax-axempt bond financing.

TABLE XI

INTEREST COST COMPARISON OF A TAX-EXEMPT AND TAXABLE CORPORATE FINANCING FOR A REPRESENTATIVE ISSUE OF $\$ 1,000,000$ OF TWENTY-YEAR BONDS.

Interest at Interest at Fully

Bonds Principal Tax Exempt Taxed Corporate

Year Outstanding Amortization Rate of $5 \frac{1}{2} \%$ Rate of $7 \frac{1}{2} \%$

$\begin{array}{rrrrr}1 & \$ 1,000,000 & \$ & \$ 55,000 & \$ 75,000 \\ 2 & 1,000,000 & 0 & 55,000 & 75,000 \\ 3 & 1,000,000 & 0 & 55,000 & 75,000 \\ 4 & 1,000,000 & 0 & 55,000 & 75,000 \\ 5 & 1,000,000 & 62,500 & 55,000 & 75,000 \\ 6 & 937,500 & 62,500 & 51,563 & 70,313 \\ 7 & 875,000 & 62,500 & 48,125 & 65,625 \\ 8 & 812,500 & 62,500 & 44,688 & 60,938 \\ 9 & 750,000 & 62,500 & 41,250 & 56,250 \\ 10 & 687,500 & 62,500 & 37,813 & 51,563 \\ 11 & 625,000 & 62,500 & 34,375 & 46,875 \\ 12 & 562,500 & 62,500 & 30,938 & 42,188 \\ 13 & 500,000 & 62,500 & 27,500 & 37,500 \\ 14 & 437,500 & 62,500 & 24,063 & 32,813 \\ 15 & 375,000 & 62,500 & 20,625 & 28,125 \\ 16 & 312,500 & 62,500 & 17,188 & 23,438 \\ 17 & 250,000 & 62,500 & 13,750 & 18,750 \\ 18 & 187,500 & 62,500 & 10,313 & 14,063 \\ 19 & 125,000 & 62,500 & 6,875 & 9,375 \\ 20 & 62,500 & 62,500 & 3,438 & 4,688 \\ & & & 37,504 & \$ 937,504\end{array}$

Table XI shows the "Interest Cost Comparison of Tax-Exempt and Taxable Corporate Financing for a Representative Issue of $\$ 1,000,000$ of Twenty-Year Bonds." During the first four years of the financing there is no principal payment. The million dollars are then repaid in 
sixteen equal payments, with the first payment starting at the end of the fifth year. A representative tax exempt rate such as might apply to industrial revenue bonds for a better credit rating is given here as $5 \frac{1}{2}$ percent. At this rate, a corporation reimbursing public agency for actual financial costs will pay a total interest cost of $\$ 687,504$ over the life of the loan. A representative taxable rate for the same cor poration borrowing in the private market is given as $7 \frac{1}{2}$ percent (prime interest rates have'increased since these calculations were made), making the interest cost total $\$ 937,504$ over the life of the loan. Financing a project. by fully-taxed corporate bonds, instead of utilizing industrial revenue bonds, will result in $\$ 250,000$ more expense, which is $36.4 \%$ higher than with the other method. Obviously, for a capital intensive firm this can mean a significant cost difference.

In spite of this possible importance of financial incentives, the Alabama study previously cited also stressed the need for other basic requirements. It concluded by saying that:

Nevertheless; the response pattern indicates that collateral influences such as market access, available labor, and suitable plant sites must be present in sufficient degree. In other words, unless alternative plant sites are reasonably comparable in terms of conventional location factors,. the costsaving features of industrial bond financing will be insufficient to cause a shift away-from a site where industrial bond financing may not be available. 45

The example of Alabama is supported by surveys in other geographical regions. One such survey reviewed state financial incentive programs in fifteen states, primarily in the New England region. Overall, state loan programs evoked a highly favorable response with 59 ${ }^{45}$ Ib id. 
percent of respondents saying that this had influenced their location decision. Subsidized interest rate programs in Pennsylvania and New York produced quest ionnaire responses of 77 percent and 72 percent; respectively, claiming such subsidies had 'very much' or 'much' influence on their investment decisions. 46 . Here again it was stated that the firms had also satisfied themselves as to the availability of other necessary factors.

On the basis of published surveys and studies, then, financial. incentives of various types would appear to offer.promise as a tool for attracting industries to states where they may not otherwise locate. In seeking optimality in the location decision, however, the investor will still require that other economic conditions be satisfied. So state financial inducements must be regarded as a marginal influence rather than constituting a primary factor. Nonetheless, that marginal influence is positive for a state desiring to attract new industry, and attracting industry to the state, or encouraging expansion within the state, is a necessary requisite to influencing its location within the state.

\section{TAX INCENTIVES}

Tax concessions of various kinds are another widely-used form of industrial location incentive. The property tax is most commonly used for the incentive, although other taxes might also be used. The effect of a tax reduction or complete removal is similar to that of a wage or capital subsidy in that it lowers the average costs for the firm. As in

\section{${ }^{46}$ G. W. Sazama, "State Industrial Development Loans: A General} Analysis," Land Economics 46:171-80. (Maỳ, 1970). 
the case of subsidized capital expenditures, there have been many surveys and studies which have attempted to determine the effect of taxes. in influencing industrial firms to locate in an area where they might otherwise not go. Their conclusions produce mixed results.

The importance of tax rates, when viewed as differentials between localities, is generally minimized as a location factor. The principal reason for this is that the differential costs of other factors such as labor and transportation are usually greater between different areas than are the differential costs of taxes. While the total costs of the taxes must be considered as an important part of the costs of doing . business, only the differentials are important in comparing the relative costs of taxes in various locations:

A 1960 study $^{47}$ showed taxes ranked thirteenth on a list of location factors in a survey of 272 firms which had built plants in Kentucky, Tennessee and Mississippi. Only 32 firms out of the 272 indicated that the tax structure influenced their choice of location and only seven of these 1 isted it as of primary importance!

A Colorado study produced similar results: 48 The findings were based on 253 usable returns from manufacturing firms which were questioned as to their reasons for locating in Colorado. Taxes ranked twenty-seventh out of the thirty items listed with only 12.7 percent of the firms indicating any consideration had been given to colorado's

${ }^{47}$ Thomas Bergin, "Are Subsidies Worthwhile?" Industrial Development (July, 1960), pp. 77-78.

${ }^{48}$ W.E. Morgan; "The Effects of State and Local Tax and Financial Inducements on Industrial Location" (unpublished Ph.D. dissertation, University of Colorado, 1964). 
state and local taxes in making their location decisions. This position is summarized by the statement that:

If all other factors could be assumed equal, it follows that differences in taxes would influence locational becisions. But other factors push in various ways and are often bigger than tax costs. In most studies based on the interview technique, industrialists tend to agree that taxes are a secondary consideration in location choice. 49

The conclusions reached by these studies can be more easily understood by reviewing applicable statistical data. For example, it is possible to obtain data which show that taxes are a relatively small percentage of total business costs. Helen A. Cameron, in her article "Property Taxation as a Location Factor," used figures from the 1963 Corporate Income Tax Returns to show tax costs as a percentage of costs and operation for selected industries and dollar assets. ${ }^{50}$ Using her format, but changing the data to show statistical calculations from the 1969 corporate tax returns, the following table is obtained:

TABLE XII

TAX COSTS AS A PERCENTAGE OF COSTS AND OPERATION FOR SELECTED INDUSTRIES AND DOLLAR ASSETS - (ASSETS IN $\$ 1,000^{\prime} s$ )

\section{INDUSTRIES}

Printing \& Publishing Leather $\&$ Leather Prod. Primary Metals Fabricated Metals Machinery (except elec.) Electrical Equipment Trans. Equip. (except auto) Motor Vehicles

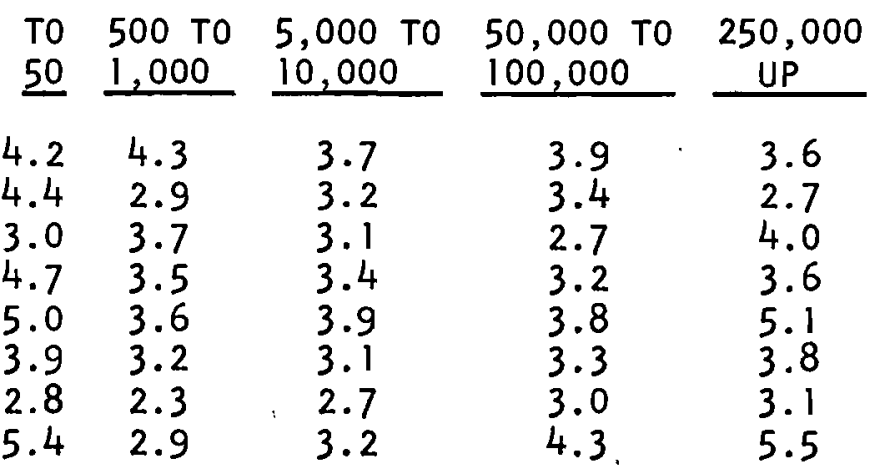

49

Richard W. Poole, "An Approach for Evaluating the Impact of State-Local Taxes on Industrial Location" New Mexico Business Vo1. 23, (June, 1970), p. 8.

"50 Helen A. Cameron, "Property Taxation as a Location Factor," Bulletin of Business Research, Ohio State University, (April, 1969), p.1. 
Data from federal corporation income tax returns show ali deductible taxes in one figure and this was used to determine the percentage of total operating costs. However, that tax figure includes "ordinary state and local taxes paid or accrued during the year; social security and payroll taxes; unemployment insurance taxes; and business 1 icense and privilege taxes:" Because of this wide variety of taxes included, the calculations overstate the significance of property taxes as a.: business expense.

Looking at property tax differentials, then, we are considering a percentage of a relatively small business cost item. An examination of the differential property tax rates in Oregon will give some indication of how wide the variations are in this state.

Table XIII shows that the spread between the highest and lowest property tax rates in Oregon in $1969-1970$ amounted to $\$ 18.83$ per $\$ 1,000$. of true cash value. That spread, however, occurred between two counties which both ranked poorly in the indicators of economic health: "the highest, Hood River County, ranked 28, and the lowest, Wallowa County, ranked 33 out of the 36 counties. The margin between the rapidlygrowing Willamette Valley counties and the poorer areas of central and: eastern Oregon was less than the margin between the two extremes.

The comparison of rank in. tax rates with rank in economic health indicators was made because of another consideration important to policy decisions." That is, how much can a local area afford to forego in tax. revenues in order to provide tax incentives to industry. "This will be considered in more detail in the next chapter when fiscal costs are reviewed, but it can be pointed out here that there is often an inverse relationship between tax rates and the need for economic improvements: 
TABLE XIII

AVERAGE PROPERTY TAX RATES IN OREGON COUNTIES; $1969-1970^{51}$

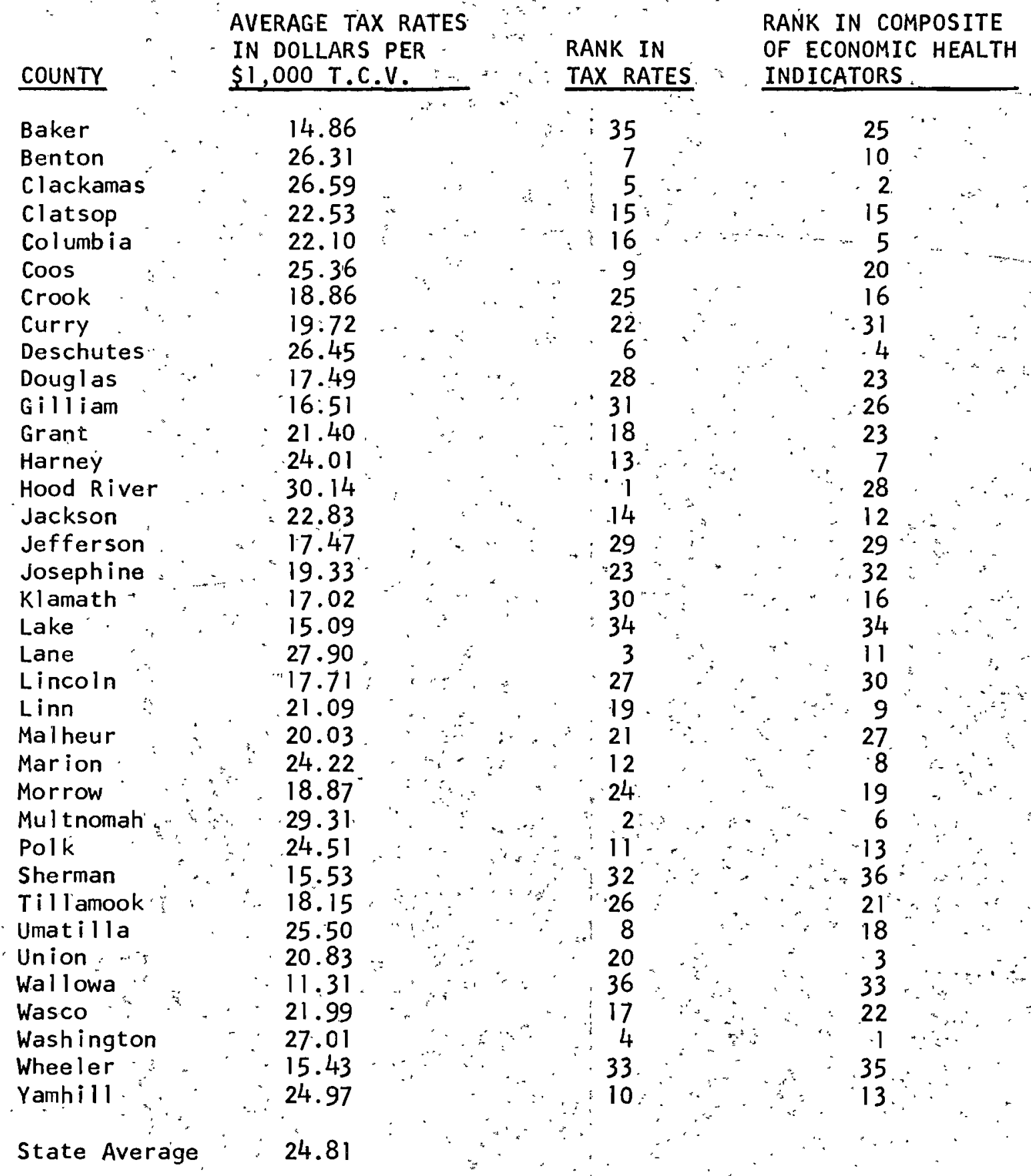

51 Oregon Division of Economic Development, District Facts (Salem: Oregon Printing office, 1972). 
Many of the counties that show the poorest levels of economic health also have among the lowest property tax rates in the state. In addition to the policy implications this involves, it also reconfirms that low tax rates are not necessarily" an inducement to industrial location since industry has established a pattern of locating in areas where tax rates. are relatively higher.

Assigning tax considerations to a secondary role, however, is not sufficient to discredit the potential usefulness of tax credits in regional development programs. With the acceptance that taxes play only a marginal role in business investment decisions, there are still some facets of that role that have implications for policy and planning by state development agencies.

- One of these relates to the "tax climate," or the structure of taxation. One of the more thorough studies of the effects of taxation on industrial location addressed itself to this question. 52 It found that the "tax, image" of a state or locality is an important variable in industrial location decisions. In making up this tax image, certain features of state and local tax structures were considered as 'favorable $i$... or 'unfavorable'. of primary importance was the concept of a broad: based tax structure which divided the tax burden between industry and other revenue sources: The level of property taxes and income taxes determined whether a tax structure was favorable or unfavorable; while inventory taxes and personal property taxes were generally regarded as unfavorable in all cases.

52 A Report of the Committee on Intergovernmental Fiscal Relations: Property Taxation and Interstate Competition for Industry, Proceedings of the National Tax Association (1967), p. 336 
Property taxes were considered favorable if the state has: (1) relatively moderate assessments or tax rates; (2) certain property tax exemptions, particularly no personal property or inventory taxes; and (3) fair or uniform assessment administration. Conversely, a state would have an unfavorable property tax image due to: (1) "high" property taxes; (2) personal property or inventory taxes; or (3) inequities in property assessments.

This study confirmed the secondary importance of taxes among other location factors but still gave taxes a significant role. In regard to property taxes, it states that:

In the industrial location decision process, property tax differentials have 1 ittle, if any, wide regional influence. In this selection process, most respondents viewed property taxes as being more important in the state of 'narrowing the choice to a few communities' or in 'selecting the final site'. This assumes a reasonable similarity in other more important economic costs: proximity to materials and markets as well as labor and land costs. $53^{\circ}$

Another extensive study of this subject found similar results. State-Local Taxation and Industrial Location has been termed "one of the most comprehensive summaries of taxation materials related to industrial plant location ever done. ${ }^{154}$ It also finds that taxes are of relatively low importance in the selection of a location for new industrial plants, when measured between regions. It states that:

Between distant states, tax differentials appear to exercise little plant location influence. The plant locator will ordinarily select the region on the basis of economic rather than tax factors. At this first stage in the selection process, accessibility to markets and materials, the character of

$$
{ }^{53} \text { Ibid., p. } 337 .
$$

${ }^{54}$ Frankl in Jones, "Taxation and Industrial Location," New Mexico Business Vol 23 (June, 1970), p. 1 . 
transportation facilities and the size of the labor cost differentials stand out as the more important locational factors. 55

However, the study goes on to say that: "Within a state and more particularly within a metropolitan area significant local property tax rate variations can and do become.swing factors in plant location decisions."

So far, then, we can conclude that taxes can affect plant location decisions by virtue of the "image" they create through their structure, and at the local level through differentials that may exist when most other costs are fairly well equalized. There are some additional tax considerations which affect location decisions, though. For instance, there is evidence that growth and changes in taxes are more significant than tax levels. 56 One study summed the importance of this consideration by saying that: "A stable tax structure is evidence of a stable state or community, and economic stability has an allure that no tax break can ever outshine. " 57

From these examples, it would seem that states and municipalities should be more concerned about devising broad-based and stable tax structures than with concessions. It appears doubtful that the forgiving of taxes would be sufficient to compensate for higher costs for other factors. Where other factor costs are equalized, a sound tax structure may be the best inducement: .

${ }^{55}$ Cited by Cameron, op. cit., p. 1.

56 Thomas F. Hady; "Tax Structure and Regional Economic Growth: A Comment," Journal of Regional Science Vol. 9, No. 2 (August, 1969), 325-6. 57 Jones, op. cit., p. 4. 
The relationship between taxes and industrial location needs to be periodically re-examined, however, as there is evidence that tax differentials may become more important in the future. As was observed by Floyd:

Further investigation of industrial costs in various geographical regions reveals that certain types of costs are becoming more uniform among industrial sites. For example, competitive factors and the development of more efficient financial institutions are tending to equalize capital expenses among locations all over the nation. In addition, trade union activity and other factors are exerting similar influences on labor costs. Nevertheless, tax costs still continue to vary among locations because of differences in governmental policies and economic conditions among both state and local governments. The fact that tax cost data are usually available to manufacturers, whereas other cost information may not be available, tends to give additional
importance to tax differentials in locational problems.

This might be even more true if taxes should rise as a percentage of business costs. Using the corporate income tax data previously cited, it was found that taxes rose from 3.4 percent of deductible business costs in 1963 to 3.6 percent, on the average, in 1969.

It is unfortunate that more empirical evidence does not exist regarding the influence of tax concessions versus tax costs. ${ }^{59}$ Poole and others have established a corelation between location and tax costs, al though it appears minor, but there is very little evidence to show that plant locations have depended upon or been strongly influenced by tax concessions per se. Where they have been offered they have been used, of course, but this does not establish a causal relationship. Nonetheless, the ability of tax costs to affect marginal location

58 Joe Summers Floyd, Effects of Taxation on Industrial Location, (Chapel Hill: University of North Carolina Press, 1952), p. 23.

$59_{\text {Poole, op. cit., p. } 6 .}$ 
docisions once the general area has been, selected infors that tax concesslons may bo a useful tool for influencing the location of Industry within local areas. No dramatic results should be expected, however. 


\section{CHAPTER $\mathrm{V} *$}

\section{BENEFIT/COST CONSIDERATIONS FOR INDUSTRIAL SUBSIDIES IN OREGON}

The previous chapters have examined the objectives of a development subsidy program, the types of subsidies that might be employed along with their respective effects on resource allocations, and the influence of subsidies on industrial location decisions. Throughout the analysis, considerations which specifically related to Oregon have been mentioned. In this chapter, we will review some additional factors which influence the effectiveness of subsidy programs on regionai economic development particularly as they might apply to oregon, as well as examining some of the fiscal implications of subsidy policies.

Earlier in this study it was mentioned that the economic structure of the region will have a major bearing on the effectiveness of a subsidy program. A report prepared for the Office of Regional Economic Development in 1966 analyzed this condition. 60 In looking at the shortrun economic and fiscal impacts of a new autonomous enterprise in an area, it establishes a hypothetical plant profile and traces the income flows through two models, one for a "large" area and one for a "small" area. The large area was one that could supply most of the specialized -products needed by the manufacturer, along with more generalized needs . such as office supplies, maintenance materials and business services.

${ }^{60}$ Industrial Location as a Factor in Regional Economic Development, prepared for the Office of Regional Economic Development by Management \& Economics Research, Inc. (August, 1966): 
In the small area, however, many of these products and services had to

be purchased from outside the area.

obviously, more of the income flows could be retained and recirculated in the larger area. The models used produced an income multiplier of 1.8 in the large area, versus only 1.3 in the smaller area.

The long-run impacts were equally variable. In assessing this aspect of the growth process, the study states:

Whether or not a new plant will act as a catalyst in the growth process to bring about a change in the economy out of proportion to the short-run stimulus will depend on the way the new plant interacts with other activities in the area and on other circumstances. Thus, two areas experiencing similar short-run impacts could have very different long-run impacts. Only a detailed study of conditions in each area will yield reasonable hypotheses about the dynamic impact of plant location. 61

A study of industrial subsidization in West Virginia confirmed

this statement. It estimated that the income multiplier of new industrial plants in that state would range between 1.8 and 2.8 , "depending upon the industry considered" and its location within the state. 6

Richardson also recognizes this condition. He states that:

If a region suffers from unfavorable input-output access for most activities, an influx of new industrial plants will not solve its problems for the new industry will tend to assimilate the depression characteristics of the region as a whole. If out-migration is rejected for a region of this kind, its problems would have to be handled by much more extensive measures--such as rebuilding its infrastructure, stimulating its adaptability to change, and investment in input-output access improvement. 63

Obviously, then, simply moving in new industries cannot be consid-

61 Ib id., p. 46.

${ }^{62}$ The Contribution of Local Subsidies to the Economic Development of West Virginia, 1956-1966, West Virginia Center for Appalachian Studies and Development, West Virginia University (January, 1969).

${ }^{63}$ Richardson, op. cit., p. 400 . 
erod as a universal panacea for solving the economic problams of all deprossod rogions. To attempt to assess the benefits of a regional subsidy program in oregon would first require detailed analys is of the regional economic structure to attempt to measure the potential efficiencies of various locations.

If such an analysis were performed, it would have implications for state policy. Some authors have suggested that efforts aimed at creating émployment opportunities for rural workers. concentrate upon locating those jobs in smaller urban centers within commuting distance of the target areas, rather than with in the target areas themselves, as a means of creating a larger number of employment opportunities. In that way, the social objectives of the subsidy program might be more easily attained without large investments in overhead costs and without the risk of creating a permanent subsidy situation due to inefficiencies of the economic structure in the more remote locations. 64

Such a policy would follow the "growth center" concept, whereby those areas within the region which have the greatest potential for development are singled out for assistance: As those areas develop, externalities resulting from their economic growth enable surrounding areas to receive beneficial spread effects.

This kind of policy was advocated in one of the Canadian studies, previously cited. In recommending future action, the study states:

One of the major elements of a regional development programme for Northwestern Ontario will be a concerted effort to induce industry to locate in those places where there is the greatest

64"Rural Industrialization and Other Employment-Generating Activities," American Journal of Agricultural Economics, Vol. 52(5) (Dec., 1970) ipp. $734-735$. 
potential for success and which have the capability of influencing the economic well-being of the region at large. Growth points are necessarily urban places, or places which are accessible to a population sufficiently large to sustain the economic growth process. In Northwestern Ontario the major criterion for growth point selection is accessibility--accessibility to resources, to major markets and to other places in the region. 65

Concentrating on growth centers appears to produce the highest. economic return for an area, primarily because of the higher multiplier effects. The Canadian study cited, for example, showed very significant secondary and tertiary employment and income effects generated by induced primary investment in the growth centers.

This does not mean, however, that investment in isolated areas will not provide local benefits. This can be demonstrated by another comprehensive study which involved five small communities in Kentucky. ${ }^{66}$ The major criteria used in selecting the study towns were that they were located outside SMSA's, that they had small populations (between 1,000 and 5,000$)$, and that at least one new manufacturing plant employing at least 100 people had been established in the community during the study period of 1958-1963. Other selection criteria were used to ensure that no major economic development other than the new manufacturing activity had occurred during the study period and that adequate data on the effects of the new plants were available. Towns tied to the economies of neighboring larger cities were eliminated from consideration.

The five rural towns selected for the study ranged in population from 1,125 to 4,813 , and the economies of the counties in which they were located were dominated by agriculture, with manufacturing accounting

\footnotetext{
${ }^{65}$ The Northwest Ontario Regional Development Program, op. cit., p.58. 66 Charles B. Garrison, "New Industry in Rural Areas: The Local Economic Impact", Tennessee Survey of Business Vol. 6 (Apri1, 1971).
} 
for only six percent of the study counties' basic incomes in 1958. The communities were also characterized by low incomes. Per capita incomes of the five counties in 1958 ranged from $\$ 596$ (29 percent of the national average), to $\$ 995$ (still less than 50 percent of the national figure).

The composition of basic income was changed substantially by the location of the new manufacturing plants during the 1958-1963 period. In 1963, the percent of the five counties' basic incomes attributable to manufacturing had $r i$ sen to 12.1 , and 52.9 percent of the manufacturing income was generated by the new plants. In terms of employment, manufacturing increased its share of basic jobs from 7.8 percent in 1958 (767 of 9,803$)$ to 19.4 percent in $1963(2,075$ of 10,688$)$.

It can be observed that there was very little growth in secondary and tertiary employment. There was also virtually no population growth. This was attributed to a high degree of underemployment prevalent in the five counties which resulted in workers shifting to the higher-paying manufacturing jobs. The major effect, then, was an increase in the marginal revenue product of labor, producing an income effect that was directly beneficial to the residents of the study area.

Which policy, or combination, should be undertaken in Oregon will primarily depend upon determination of objectives. A policy which is directed toward growth centers would appear to have greater probability of attracting new industries to the region as growth centers can provide more easily the various economic factors which have already been identified as being more important in the location process than subsidies. Growth centers also offer greater opportunities for expansion of secondary and tertiary employment, thus accelerating the growth process and inducing population shifts. If growth centers are not the focal point 
of State policy, however, benefits of industrial subsidization can still be realized for the residents of rural areas.

As. a corolary to the problem of differences in regional economic structure, not all types of industrial firms will produce similar stimuli to sustained growth. For this reason, Richardson suggests the importance of selective inducements rather than blanket; indiscriminate aid to all types of firms and all industries. He says that industries which give rise to substantial intra-regional factor receipts and the products of which exhibit high income elasticities of demand may deserve preferential treatment on the grounds that they increase effective demand as well as employ underutilized resources.

Studies of industrial inducement programs in the United States, however, generally indicate that they are not used for inefficient industries. While selection criteria for subsidy recipients vary between states, on overall balance the results appear to be positive: One criticism levied against, subsidization programs is that they attract only low-quality companies which.will stay in the area-only as long as their subsidy makes it profitable to do so. ${ }^{68}$ A corolary. contention is that the types of firms most sensitive to financial inducement programs are generally those which are labor intensive rather than. capital intensive, which produce a low dollar value per worker and which generally pay low wages. ${ }^{69}$ If those criticisms were valid, it is doubtful

67 Richardson, op. cit., pp. 402-403.

68 Marsom B. Pratt, "A Banker Views Subsidies and Inducements,". Industrial Development, (March, 1963), Pp: 5-7.

69 Morgan, op. cit:, p: 152 
that attracting such industries will lead to substantial long-run industrial improvement.

Studies of the actual use of subsidies do not support these conclusions, however. "In the Alabama survey, cited by Thompson, 70 it was found that 38 firms using industrial bonds and placing them high on the list of locational determinants included 15 of the 19 "nationally-known". firms which responded to the questionnaire. As was al so pointed out earlier, those firms invested more than twice the national average capital per worker.

In fact, the very nature of industrial subsidies makes them more condusive to use by capital-intensive firms than as labor subsidies. This fact should be recognized by state agencies because of its implications. If Oregon adopts a capital subsidy program, it should anticipate that its major use will come from firms with high capital requirements." Using the Alabama survey as a guide, Oregon might expect to have to subsidize an average investment per job created about twice the national average. A policy aimed at keeping the costs of subsidization propor-tionately low would have the effect of defeating the purpose of capital subsidies:

Trying to assess the potential benefits for oregon from the adoption of an industrial subsidization program, then, will depend upon the objectives of the policy and the methods employed. Once defined development objectives have been established, an economic base analysis will provide information as to the number of primary jobs and level of induced income that need to be generated to accomplish those objectives.

${ }^{70}$ Thompson, op. cit. 
Different areas can then be compared for their potentials and development strategy can concentrate upon locations where there is the greatest promise of accomplishing the objectives:" It must be recognized, however, that different results will be produced in different areas and from different methods.

\section{Fiscal Costs}

The financial costs to government resulting from subsidy programs will also vary according, to the methods used. Loan guarantees, for example, involve practicaliy no direct costs, other than administrative, unless the firm being subsidized should default. At the same time, loan guarantees are not one of the more successful forms of inducements so their return, even for the small costs involved, may be marginal.' It must be considered also that governmental agencies generally have large borrowing requirements to finance their own projects and rely upon their credit positions to ensure low interest rates. "Lack of discrimination in underwriting industrial loans could jeopardize this position.

The granting of direct loans has similar implications attached to it. In this case, however, a direct transfer of public funds is involved. These funds can be obtained either from revenue sources, such as taxes, or from borrowing. Borrowing offers the advantage of attracting mobile capital from outside the area and deepening the capital base. Again, however, it may $1 \mathrm{imit}$ the borrowing power of the state to finance other projects or increase the costs of those projects by increasing-interest costs.

Direct loans are often made by a governmental agency from general tax revenues or the sale of tax exempt bonds. An analysis of both types 
of loans was made by Sazama,' who used the bond-financed program of New York and the tax-financed program of Pennsylvania as models, and compared them with programs in other states which relied on borrowing. 71 He concluded that on the whole, state loans have a positive net benefit by inducing a net increase in state income. Accordingly, he stated. that more tax revenue would be induced than foregone.

However, in looking at the alternative types of loans, he decided that a program financed by borrowing would be definitely superior to a direct loan program financed by taxation:- When a program is financed by borrowing, the repayment of loan principal can be used to amortize the state debts originally incurred. Interest and fees would usually be sufficient to cover operating costs and losses. A tax-financed program, on the other hand; would not be self-financing until there were sufficient loan repayments to cover new loan disbursements. If the annual loan volume were held constant, this would require a period of years equal to the average term of loans outstanding:

Other studies of tax-financed loans or tax exempt revenue bonds' seem to support the contention that the overall results are positive; - at least on the state and local level. In assessing the Alabama program, for example, Thompson estimated that industrial revenue bonds had attracted roughly 60 firms and 17,000 jobs to the state during the 19581968 period. Without these jobs, he estimated that Alabama residents would annually lose an estimated $\$ 100$ million in wage and salary income, ignoring completely any multiplier effects.. Per capita incomes would be one to two percent lower. He further estimates that state and local tax

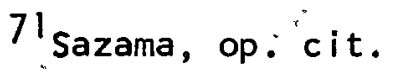


revenues are between $\$ 4-5$ million greater because of the increased invostmont and incomo. Ho places the cost to the U.S. Treasury at $\$ 18$ million on $\$ 785,697,000$ of tax-exempt bonds, but indicates significant recovery of much of this loss from the added taxable incomes. ${ }^{72}$

Much more detailed analysis is possible regarding the fiscal effects of tax supported loans but, on balance, it would appear that they produce net benefits.

It is hard to find supportive evidence for tax concessions, however. Most such concessions have been related to the property tax where the direct impact is felt most strongly by the local governments that have to provide the services needed by new industry. Hale has observed that:

Numerous studies suggest that where tax exemptions are granted to local industry, the public service requirements of the industry may force increases in taxes if the quality of public services is to be maintained. However, in many depressed areas what is of ten required is an improvement in public services. This, of course, means that local taxes must increase for the non-subsidized portion of the community and that the subsidy cost is much greater than the amount of revenue foregone by not taxing the subsidized plant. 73

This consideration has direct relevance for Oregon when it is remembered that those counties which appear most in need of development al ready have some of the lowest property tax rates in the state.

This view also becomes significant when it is remembered that tax concessions will be used, when they are available, regardless of whether they are crucial to the investment decision. A Louisiana study of 609

72 Thompson, op. cit.

${ }^{73}$ Carl W. Hale, "The Optimality of Local Subsidies in Regional Development Programs: Reply," Quarterly Review of Economics and Business Vol. 10 (August, 1970), 88-9. 
property tax exemptions involving about $\$ 355 \mathrm{million}$ in new plant and equipment makes this point. ${ }^{74}$ A survey found that only one plant, representing a $\$ 25$ million investment, would have been lost if the tax exemptions had not been available. To gain this one plant, in effect, the state and local governments lost $\$ 51.4 \mathrm{million}$ over a 10 -year period.

Here again, however, the structure of the program and the externalities involved should be considered. If a state program is designed to shift population and resources away from high tax cost areas to regions where incremental tax costs are lower, there may be an offsetting benefit. An example is given in a study of Washington State's highway costs which found underutilization of highways in the sparsely populated areas and congestion in the areas of population concentration. The report estimated that if 15 percent of the new population growth could be shifted to the sparsely settled areas, there would be an annual savings by 1985 of $\$ 50$ million by reducing the need for highway expenditures. 75.

While this kind of approach might partially justify the initial foregoing of taxes to accomplish long-term tax savings, it does not negate the earlier conclusions that there are less-cost ways to reach the same end.

Another consideration to the question of fiscal impact relates to the type of firms being subsidized. Kee makes the observation that

74 William L. Henderson, "Are Industrial Tax Concessions Necessary?", Arizona Review of Business and Public Administration, XIV (Feb., 1965), 8.

${ }^{75}$ Final Report on How Industrial Decentralization Could Affect Washington State Highway Costs (Richland, Wash.: Battelle Memorial Institute, October, 1968). 
78

some firms provide more local revenues while demanding fewer local services than others. ${ }^{76}$ An example would be the firm that hires pimarly secondary wage earners, thus creating little additional demand for housing and utility requirements.

The view on fiscal effects of subsidized industry, then, is. complex. When looked at from a cost-benefit position, there are many variables associated with the type of subsidy, the level of government considered, the economic structure of the region and the type of firm. By looking at all these variables, however, it should be possible to. find an optimum program -which does produce a net benefit, at least for local government, for inducing new industrial investment to depressed. areas. 
CHAPTER VI

CONCLUSION

This study has reviewed several aspects of the efficacy of induced industrial investment as a means.of stimulating economic development in" depressed areas. Its purpose was to hopefully provide information useful to the State of Oregon as it considers adopting an incentives program.

In considering the justifications, for such a program, it was found that considerable imbalance exists in the degree of economic health prevailing throughout the state. Population changes alone; which showed one-third of Oregon's counties losing population between 1960 and 1970 , might be sufficient to warrant interest in redirecting growth patterns. But of greater significance are the disparities in incomes, unemployment, population of labor-force age; etc., which give evidence that certain parts of the state are progressively becoming poorer in relation to other areas, particularly the Willamette Valley. If it can be assumed that the State has a legitimate function in trying to help its citizens achieve equity in economic opportunities, then there may be a role for State action in trying to disperse industrial investment to areas of ". economic distress. In terms of effects on gross state output and efficiency in resource allocation, however, it was shown that there are costs involyed in shifting resources to areas of lower productivity and that the principal benefits of an industrial dispersion program may be social rather than economic. 
From the research done on this study, it became apparent that various forms of subsidies can affect industrial location in different ways, but that the effects are only marginal and incentives will only. be useful where other conditions for economic efficiency exist. As this finding was virtually unanimous in all the cases reviewed, it can be assumed that it would also be true in oregon. Incentives, then, will not replace other economic factors in company location decisions. As a prerequisite to efforts to shift industries to distressed areas, analysis should be made of the economic resources available in those areas with a view toward determining their potential for efficiency in production. It may be found that other types of public investment may be necessary, such as in highways, training programs and utilities, before subsidies could become effective.

It was also found that financial incentives are generally more effective than tax concessions. This would probably be especially trüe in Oregon, where it was found that those counties most in need of économic improvement presently show among the lowest tax rates in. the state and could least afford to forego tax revenues.

Next, the possible benefits of an industrial subsidy were reviewed according to two additional variables: the economic structure of the region, and the types of firms subsidized. In this regard, the possibility of concentrating efforts on established growth centers, where the preconditions for economic efficiency al ready exist, was considered as a means of maximizing economic returns to subsidies. It was also shown that the potential users of a subsidy program tend to be firms in: capital-intensive industries, leading to the conclusion that large capital subsidies might be required to produce any significant benefits 
on labor force absorption.

Finally, the fiscal costs of an inducement program were examined. It was found that there are important variables which determine the fiscal impact of incentive programs on state and local governments but that by proper consideration of those variables a program can be formulated which produces positive fiscal benefits.

In conclusion, it can be stated that incentive programs can only influence the location of industry, not determine it. Most firms will still prefer to locate where there are inherent economic advantages, and this usually means the metropolitan areas: Where the alternatives exist, however, an incentive program may tip the balance. in favor of a smaller community in a depressed area. Considering the geographical imbalances in the oregon economy, using incentives as a means to disperse economic and population growth would appear to offer potential benefits. 


\section{A SELECTED BIBLIOGRAPHY}

Books

Axworthy, Lloyd, and Gillies, James M., ed. The City: Canada's Prospects, Canada's Problems. Toronto: Butterworth \& Co., 1973.

Drucker, Peter. The Age of Discontinuity. New York: Harper \& Row, 1969.

Floyd, Joe Summers. Effects of Taxation on Industrial Location. Chapel Hills: University of North Carolina Press, 1952.

Friedmann, John, and Alonso, William, ed. Regional Development and Planning. Cambridge: M.I.T. Press, 1964.

Industrial Aid Financing. New York: Goodbody \& Co., 1965.

Nourse, Hugh 0. Regional Economics. New York; McGraw Hill, 1968.

Richardson, Harry W. Regional Economics. New York: Praeger, 1969.

Articles

Ballaine, Wesley C. "British Experience in Influencing Location of Industry." Western Economic Journal, IV (Summer, 1966), 237-46.

Bergin, Thomas. "Are Subsidies Worthwhile?" Industrial Development, July, 1960, pp. 77-8.

Cameron, Helen A. "Property Taxation as a Location Factor." Bulletin of Business Research, Center for Business and Economic Research, Ohio State University, Vol. XLIV, No. 4 (April, 1969).

Crepas, Kenneth J. and Stevenson, Richard A. "Are Industrial Aid Bonds Fulfilling Their Intended Purpose?" Financial Analysts Journal, XXIV (Nov./Dec., 1968), 105-9.

Cumberland, J. H. and Van Beek, Frits. "Regional Economic Development objectives and Subsidization of Local Industry." Land Economics, XLIII (August, 1967), 253-64.

Fernback, Frank L. "Subsidized Plant Migration." American Federationist. July, 1966, pp. 6-12. 
Garrison, Charles B. "New Industry in Rural Areas: The Local Economic Impact." Tennessee Survey of Business, VI (April, 1971), 3-6.

Gray, Ralph. "Industrial Development Subsidies and Efficiency in Resource Allocation." National Tax Journal, XVII (June, 1964), $164-172$.

Hady, Thomas F. "Tax Structure and Regional Economic Growth: A Comment." Journal of Regional Science, IX, No. 2 (August, 1969), 325-6.

Hale, Carl W. "The Optimality of Local Subsidies in Regional Development Programs: Reply." Quarterly Review of Economics and Business, $X$ (August, 1970), 88-9.

Henderson, William L. "Are Industrial Tax Concessions Necessary?" Arizona Review of Business and Public Administration, XIV, No. 2 (February, 1965), 6-9.

Hopkinson, Richard. "Government Financial Assistance for Industrial Development in Canada." The Conference Board Record, V (Apri1, 1968), 22-3.

Jones, Franklin. "Taxation and Industrial Location." New Mexico Business, XXIII (June, 1970), 1-4.

Kee, Woo Sik. "Industrial Development and Its Impact on Local Finance." Quarterly Review of Economics and Business, VIII, No. 2 (Summer, 1968), 19-24.

Low, Richard E. "A Refinement of Local Industrial Subsidy Techniques: Comment." Mississippi Valley Journal, IV (Spring, 1969), 78-81.

Morss, Elliott R. "The Potentials of Competitive Subsidization." Land Economics, XLII (May, 1966), 161-9.

Poole, Richard W. "An Approach for Evaluating the Impact of State-Local Taxes on Industrial Location." New Mexico Business, XXIII (June, 1970), 5-11.

Pratt, Marsom B. "A Banker Views Subsidies and Inducements." Industrial Development, March, 1963, pp. 5-7.

RineHart, J. R. and Laird, W. E. "Community Inducements to Industry and the Zero-Sum Game." Scottish Journal of Political Economy, XIX (February, 1972), 73-90.

"Rural Industrialization and Other Employment-Generating Activities." American Journal of Agricultural Economics, LII, No. 5 (December, 1970), 734-5.

Sazama, G. W. "State Industrial Development Loans: A General Analysis." Land Economics, XLVI, (May, 1970), 171-80. 
Scott, John T., Jr. "Economic Impact of Industrialization on Rural Areas." Illinois Business Review, XXV, No. 8 (September, 1968), 6-8.

Site Selection Handbook, Vol. I Atlanta: Conway Research, 1972.

Thompson, A.A. "Business Experience With Industrial Aid Bonds as a Source of External Financing: Some Empirical Evidence." California Management Review, Winter, 1970, pp. 25-37.

Reports and Government Documents

Battelle Memorial Institute. Final Report on How Industrial Decentralization Could Affect Washington State Highway Costs. Richland, Washington, October, 1968.

Center for Political Research. Federal Activities Affecting Location of Economic Development. Report to the U.S. Dept. of Commerce, Washington, D.C., 1970.

Comeau, Robert L. A Study of the Impact of the Area Development Agency Program in Nova Scotia. Halifax: Dalhousie University, 1969.

Department of Treasury and Economics, Regional Development Branch. The Northwest Ontario Regional Development Program. Ottawa, October, 1969.

Fantus Company. How Much Can We Influence the Growth of Industry in Rural Areas? Report to the U.S. Dept. of Agriculture. Washington, D. C., October, 1970.

Lloyd, P. E. and Yeates, M. H. Impact of Industrial Incentives: Southern Georgian Bay Region, Ontario. Report to the Policy Planning Branch, Dept. of Energy, Mines and Resources. Ottawa, 1968.

London Board of Trade. The Policy and Practice of the British Government for Dealing with Local Unemployment. London: The London Board of Trade, 1960.

Management \& Economics Research, Inc. Industrial Location as a Factor in Regional Economic Development. Report to the Office of Regional Economic Development, Washington, D. C., August, 1966.

Morgan, W. E. "The Effects of State and Local Tax and Financial Inducements on Industrial Location." Unpubl ished Ph.D. dissertation, University of Colorado, 1964.

National Tax Association, Committee on Intergovernmental Fiscal Relations. "Property Taxation and Interstate Competition for Industry. Proceedings of the Sixtieth Annual Conference on Taxation (1967), Washington, D.C., 1967, PP. 308-79. 
Regional Development Incentives Act, Ottawa: Queen's Printer for Canada, 1969.

Report of the Senate Task Force on Economic Development to the $57 \mathrm{th}$ Legislative Assembly. Salem: State of Oregon Press, 1972.

West Virginia Center for Appalachian Studies and Development. The Contribution of Local Subsidies to the Economic Development of West Virginia, 1956-1966.- Report to the Office of Regional Economic Development, Washington, D.C., August, 1966. 


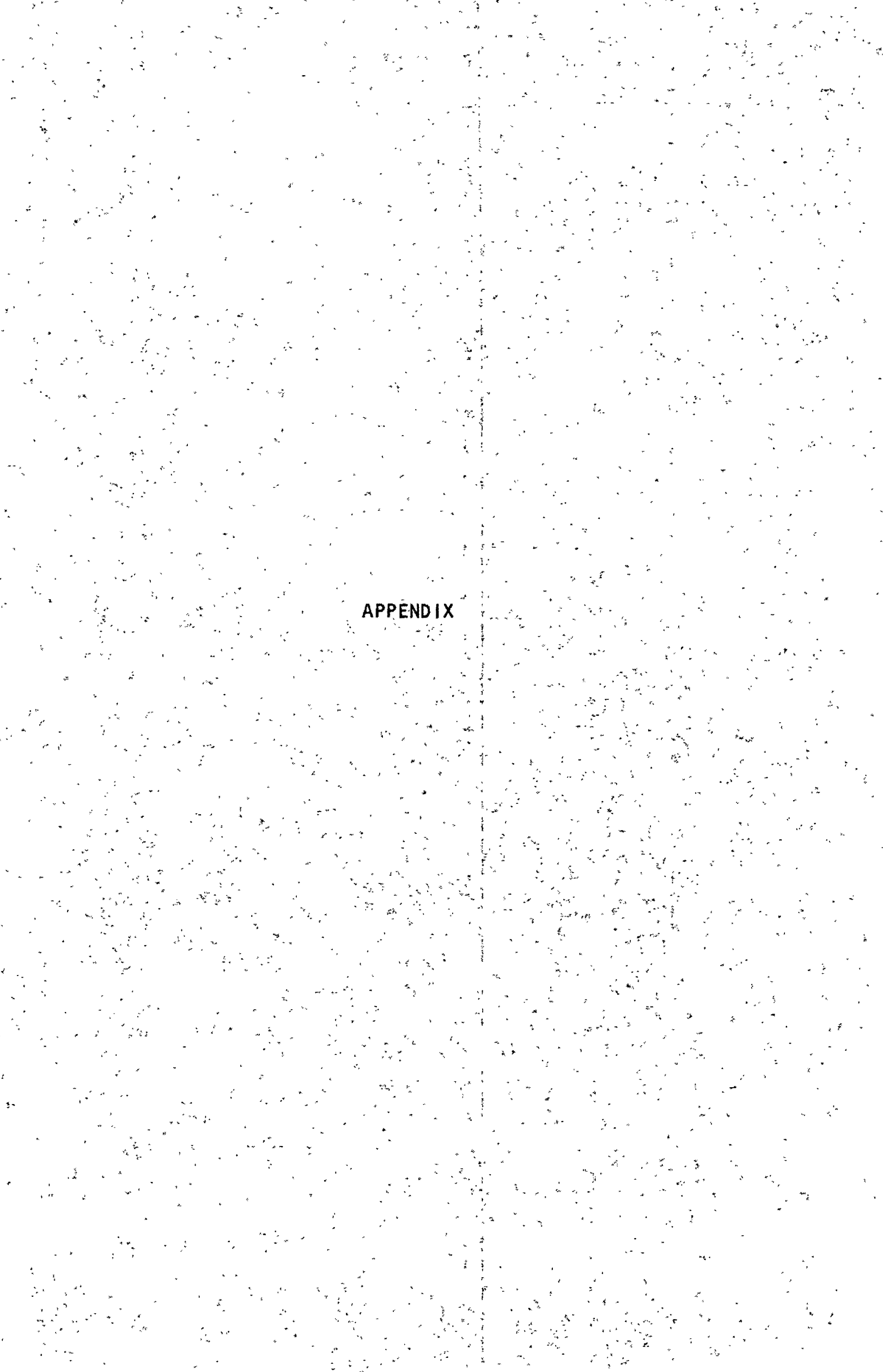


TAX INCENTIVES FOR INDUSTRY

DTHEA LAWS

Antwatta

Alnik:

Aftrana

Atkansas

Callorma

Colorado

Comecticut

Driaware

Florida

Georyia

Hawaii

Idaho

Itinols

Indiana

lowa

Kansas

Kenturky

Loulsiana

Maine

Maryland

Massachusetts

Michigan

Mirnesota

Mississippi

Missouri

Montana

Nohraska

Novada

Now Hangshtro

New lorsey

Now Mexico

Naw York

North Carolins

North Dakota

Ohio

Oklahoma

Oronon

Pennsylvanis

Rhode Islant

South Caralln

South Dakota

Tennesseb

Texas

Utah

Vermont

Virginia

Washington

Wost Virginia

Wisconsin

Wyoming
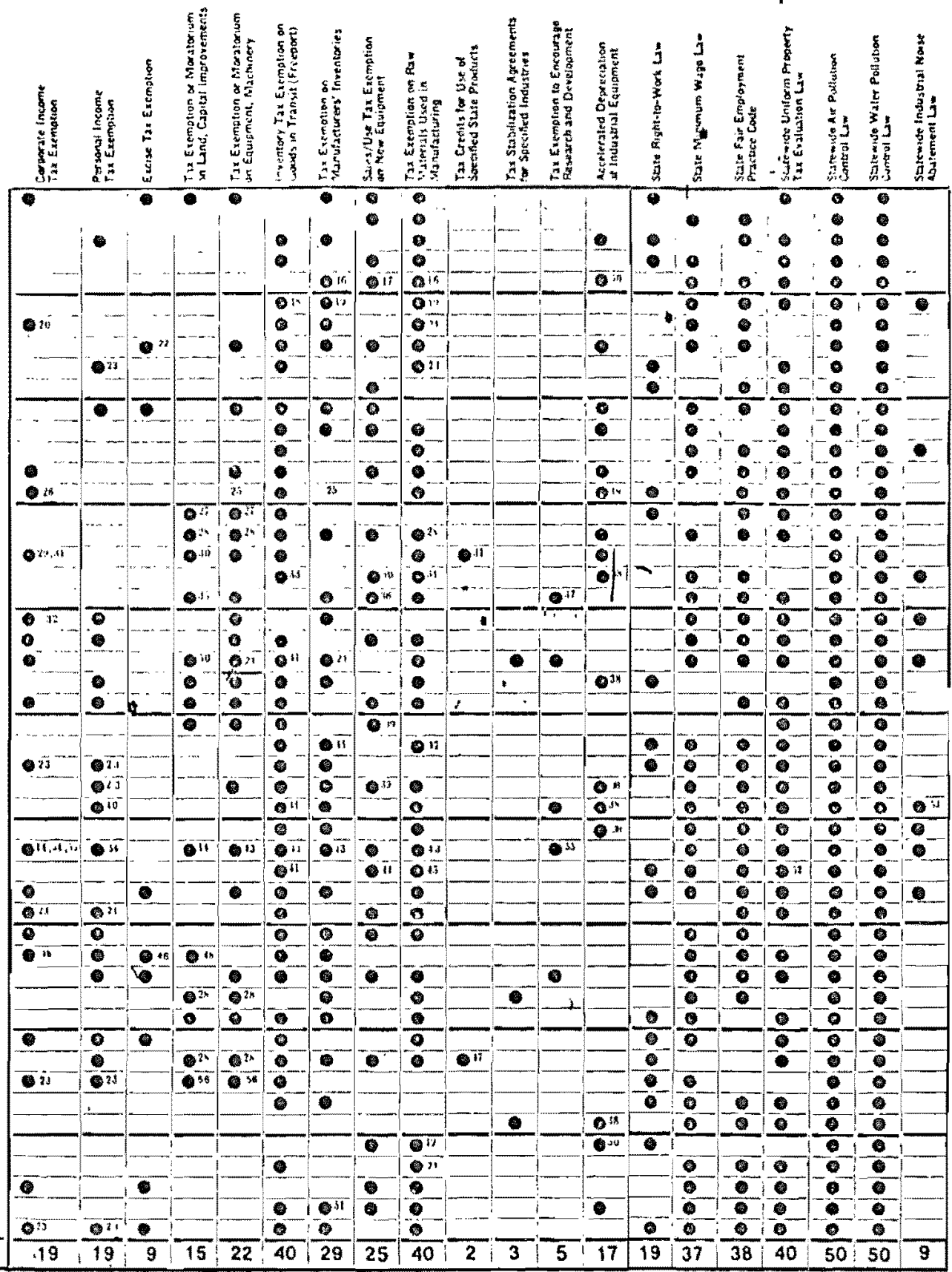

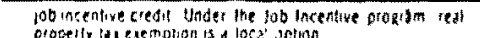

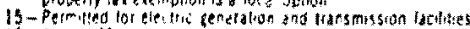

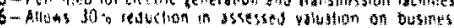

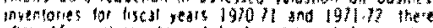

atret is untess changed by lezistature betore end of 197.

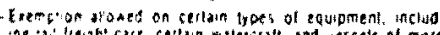

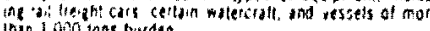

18- - (2) allows inducina in

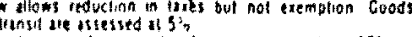

9- Harentases atd ra materials nele assessed $115 \%$ in

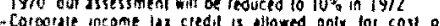

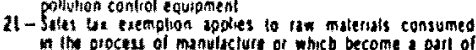

The latested crodus

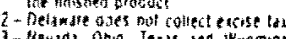

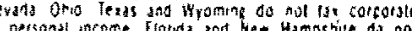
at gersonat incern

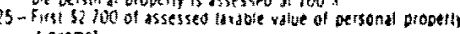

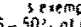

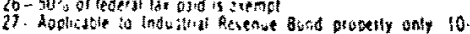

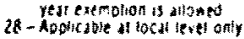

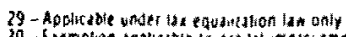

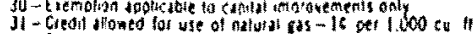

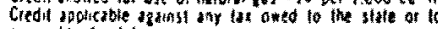

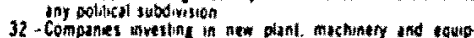

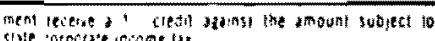

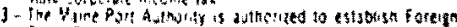

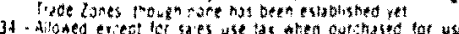

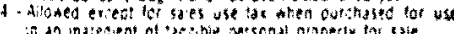

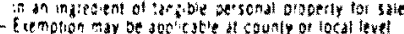

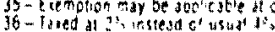

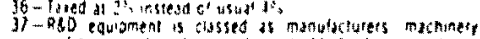

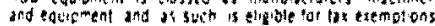

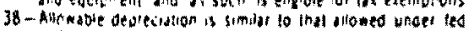

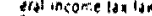

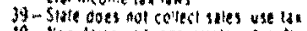

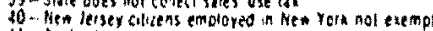

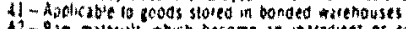

ayt of eal tent ale

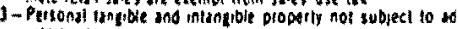


FINANCIAL ASSISTANCE FOR INDUSTRY
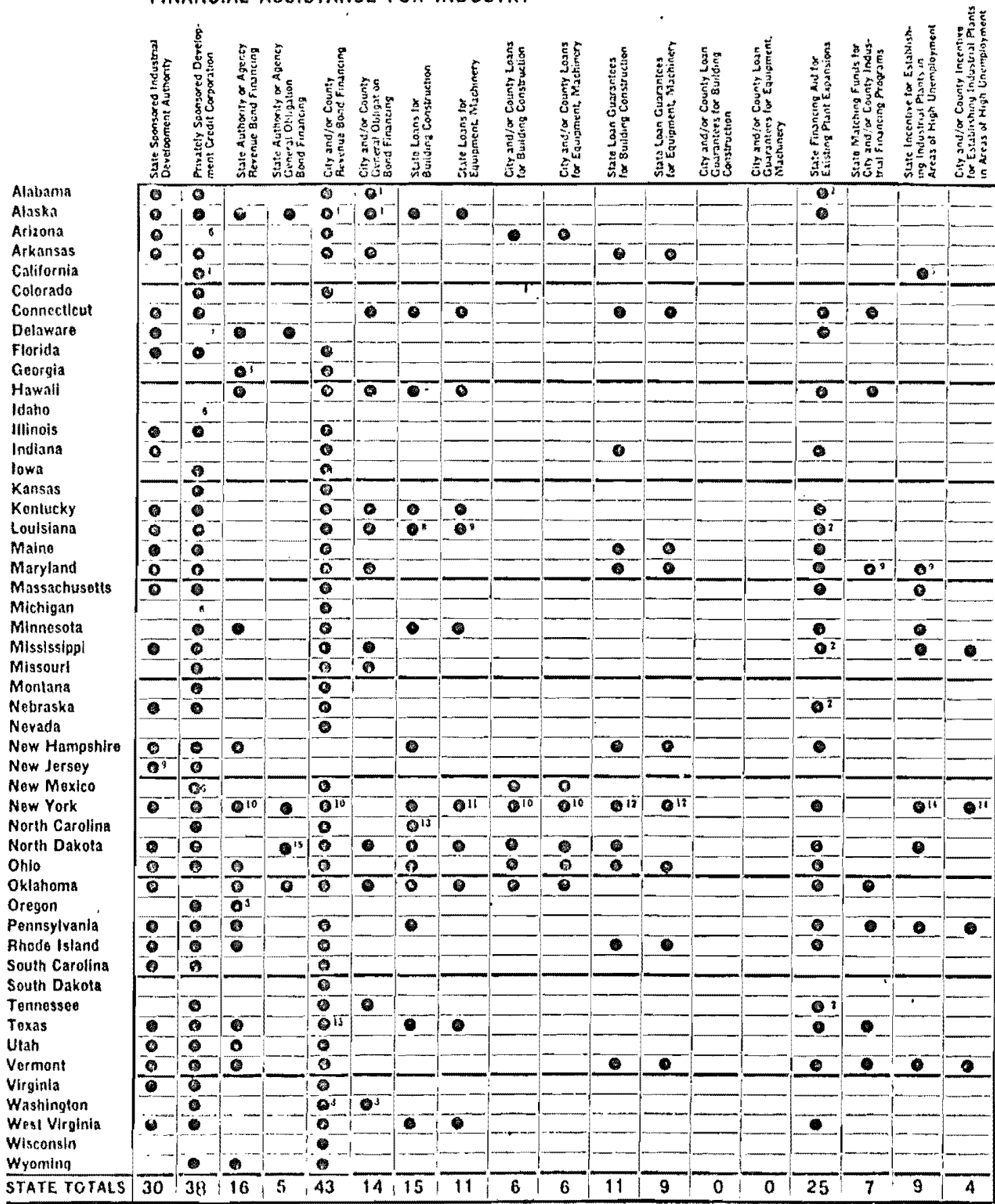

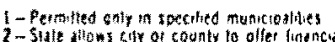

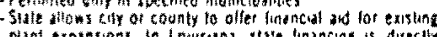

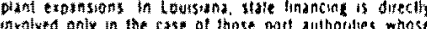

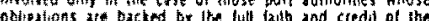

3- state

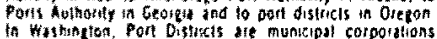

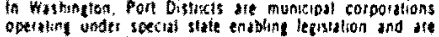

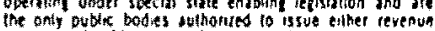
of fental oblitions bonds to linance industina of tereoments

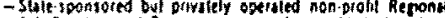

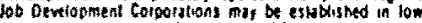
meome-1uen lo pronde bats to smat buscinesses
}

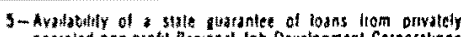

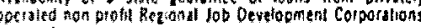

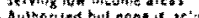

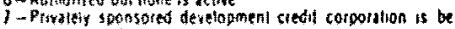
ate organted

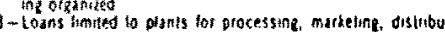

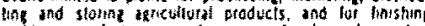

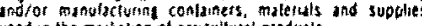

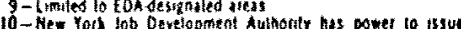

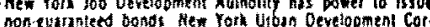

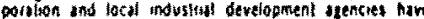

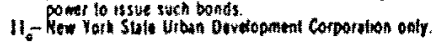

12- The bah Devtooment Guantee Fund of Kew Yolk is

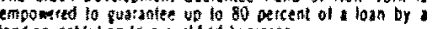

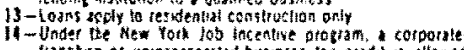

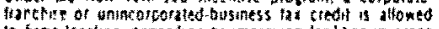

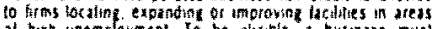

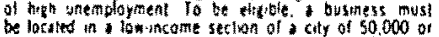

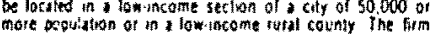

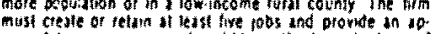

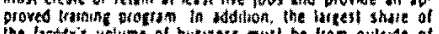

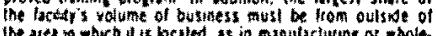

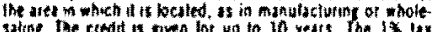

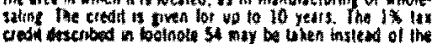


SPECIAL SERVICES FOR INDUSTRIAL DEVELOPMENT.

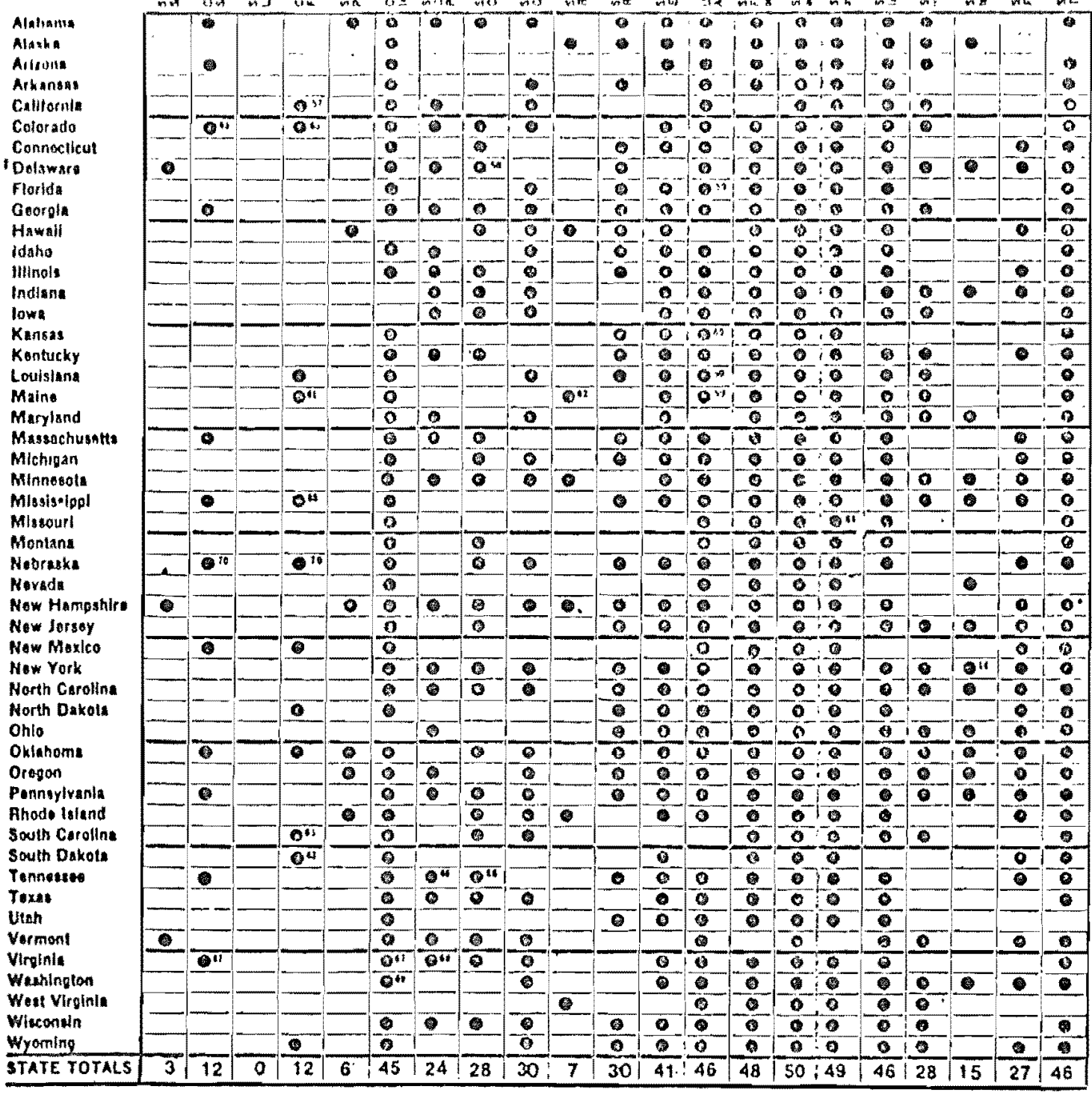

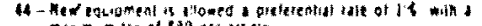

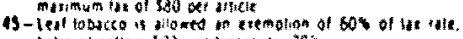

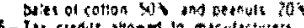

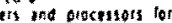

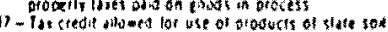

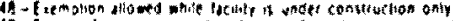

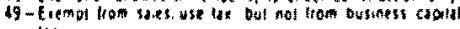

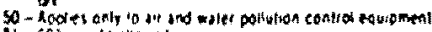

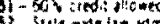

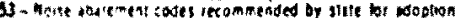

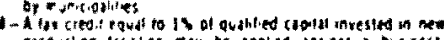

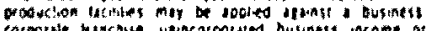

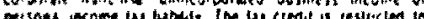

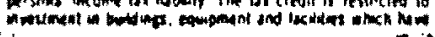

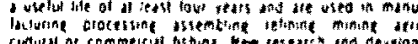

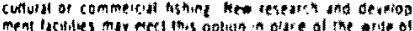

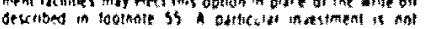

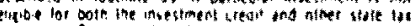

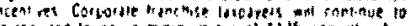

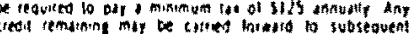
crets

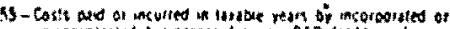

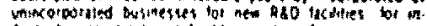

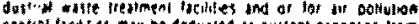

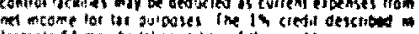

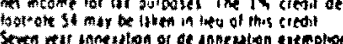

Y) - 1 tew of

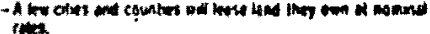
that....

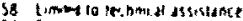

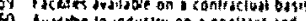

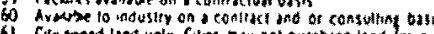

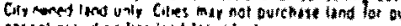

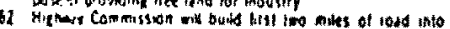
ine teis

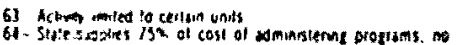
itersorfment lo ilinet:

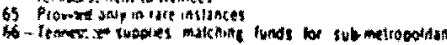

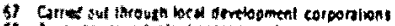

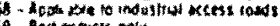

6e - Pent minkts ont

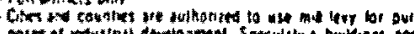

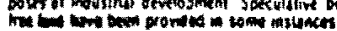

